\title{
EL ESTILO NACIONAL EN LOS SÍMILES DE LOS MÍSTICOS ESPAÑOLES Y FRANCESES
}

Trataremos aquí de estudiar comparativamente el estilo literario español y el francés según se reflejan en los símiles utilizados por los místicos. Si distintos escritores, en efecto, procuran describir un mismo fenómeno, necesariamente resultará un estilo colectivo, dentro de ese determinado terreno. La comparación entre las hablas de los escritores místicos de dos diferentes países y casi de la misma época es por tanto, para este propósito, un "careo ideal . . . pues la experiencia expresada . . . es idéntica". ${ }^{1}$ Ya en otra ocasión nos hemos referido, al comparar el estilo de Santa Teresa de Jesús con el de la ursulina francesa Marie de l'Incarnation, ${ }^{2}$ a la posibilidad de desechar ciertos rasgos como individuales o de época. Marie escribe con más sobriedad porque es francesa, porque se esfuerza en ajustarse al gusto clásico francés, aparte de que está personalmente persuadida de que las comparaciones no son compatibles con lo elevado de la experiencia mística. Pero todos los otros autores, desde San Francisco de Sales a Fénelon, recurren a comparaciones místicas, y com. piten a su manera con los españoles, famosos por este rasgo de estilo. Están obligados a hacerlo, porque las simples designaciones son a menudo insuficientes para traducir la experiencia que se quiere expresar. Lo que separa el lenguaje místico español del francés no es que el uno exprese la experiencia mística por metáforas y el otro por designaciones abstractas. Utilizándose símiles en una y otra lengua, la diferencia está en el peculiar modo de insistir en ciertos conceptos fundamentales y de desarrollar en ciertas direcciones las imágenes místicas. Puestas en claro esas direcciones, sin duda revelarían tendencias nacionales del lenguaje místico, y, por lo tanto, tendencias nacionales en general. Quizá podamos así, en este campo tan limitado, dar un primer paso para llegar a conclusiones más seguras que las de Madariaga, que estudia a Ingleses, franceses, españoles ${ }^{3}$ a base de un esquema preconcebido de hombre de acción, de pensamiento y de pasión; o las de Eugen Lerch, que analiza la sintaxis y el vocabulario del español y el francés y encuentra que, a grandes

1 Maria Rosa Lidia en su teseña de SpF, vil, 1938, en RFH, II, 1940, pág. 65.

2 Klassische Frauenmystik in Spanien und Frankreich, en SpF, viI, 1938, págs. 233-257.

3 Salvador de Madariaga, Ingleses, franceses, españoles. Ensayo de psicología colectiva comparada, Madrid, 1929. 
rasgos, corresponden al hombre de fantasía y al de razón. ${ }^{4}$ No contamos todavía con una comparación entre la mística española y la francesa, salvo en una que otra observación general ${ }^{5}$ o marginal ${ }^{6}$ que poco pueden servir a nuestros propósitos.

El presente estudio trata, por otra parte, de plantear el problema de los símiles místicos atendiendo especialmente a lo por ellos representado y no a los aspectos materiales del mundo y de la actividad humana de los cuales provienen, punto de vista hasta ahora casi exclusivo en los bien conocidos trabajos de Etchegoyen y Hoornaert sobre los símiles de Santa Teresa, y en el minucioso estudio de Fr. Luis D. Urbano sobre el mismo tema. ${ }^{7}$ Los símiles más característicos conciernen a la pasividad mística, imposible de comprenderse sin analogías, como que es experiencia no concedida al hombre común. La pasividad mística en sus diferentes aspectos es, pues, el punto de partida onomasiológico de los símiles estudiados. Esos aspectos son: $1^{\text {o }}$ la diferencia entre contemplación mística y meditación activa; $2^{\circ}$ los recursos preparatorios para la contemplación; $3^{\circ}$ la contemplación en su forma inceptiva o inicial, en forma progresiva y en forma avanzada; $4^{0}$ la purgación pasiva; 50 la unio mystica. Si se observan atentamente los distintos modos de traducirse estos conceptos en símiles, será posible descubrir la razón de esa diferencia, tomando en cuenta un número considerable de formas metafóricas utilizadas para unas mismas "cosas" metafísicas y espirituales (en el sentido de "palabras y cosas", Wörter und Sachen), llegando hasta la experiencia psíquica respectiva. Esta experiencia psíquica debe ser supraindividual, debe abarcar a todos los escritores estudiados. Debe ser nacional y no de época, porque los místicos españoles tardíos y los primeros franceses coiciden cronológicamente. El misticismo barroco español y el francés forman un mismo movimiento: el misticismo clásico de los siglos XVI y XVII.

\section{MEDITACION Y CONTEMPLACIÓN}

a) EsPAÑA: La relación entre el meditar y el contemplar es para los españoles una relación de causa a efecto. El luchador acaba por alcanzar su recompensa, dentro del espíritu de la Reconquista, o como dice Francisco de

4 EUgen Lerch, Französische Sprache und Wesensart, en Handbuch der Frankreichkunde, I, Frankfurt, Diesterweg, 1928; y Spanische Sprache und Wesensart, en Handbuch der Spanienkunde, Frankfurt, Diesterweg, 1932.

5 Maurice Legendre, Espiritualidad francesa, espiritualidad española, en VyV, I, 1943, págs. $377 \cdot 400$.

6 Baldomero jiménez Duque, Humanismo y mística, en Arbor, ili, 1944, pág. 74, nota 1.

7 Luis D. URbano, Las analogías predilectas de Santa Teresa, en CT, xxvir, 1923, págs. 364-383; xxIx, 1924, págs. 350-370. 
Osuna: "La consolación espiritual es fruto de las . . . asperezas de fuera". 8 La meditación hiere con el eslabón el pedernal, la contemplación hace brotar la chispa; 9 la una es el llamar a la puerta, la otra es verla abrirse; ${ }^{10}$ la una es el caminar, la otra el descanso final: "el trabajo de ir caminando y el descanso . . . que hay en el término", ${ }^{11}$ la una es el navegar, la otra el llegar al puerto donde "cesa la navigación". ${ }^{2}$ El meditar significa "estar guisando la comida"; el contemplar, "estar comiéndola y gustándola ya guisada y masticada". ${ }^{13}$ En un caso el duro aprendizaje del oficio ("el que aprende carpintería"), en el otro su dominio ("salir carpintero")..$^{14}$

Desde otro punto de vista, la relación entre ascética y mística es una relación entre imperfección y perfección. Estos dos términos típicos de la vida espiritual, que a cada paso encontramos en la literatura católica, los vemos traducirse, en España, en imágenes relativas al paisaje, las costumbres y el arte españoles. Así la meditación se presenta como "agua del arroyo", menos grata que el "agua de la fuente" de la contemplación; ${ }^{15}$ la una "viene de muy lejos por muchos arcaduces", la otra está "en el mismo nacimiento de agua" y nunca se seca ("siempre está procediendo agua de alli") $;{ }^{16}$ la una es comparable al trabajo de un buey lento que tira del arado y a cada instante se echa a des. cansar, la otra al trabajo de un rápido buey estimulado por el aguijón; $;^{17}$ la una es como vivir en las afueras de un castillo con gentes de baja estofa ("en la ronda del castillo adonde están los que le guardan"), la otra es como vivir en el interior del castillo con su señor ("tan precioso lugar"). ${ }^{18}$ El meditar es como la condición del escudero; el contemplar, como la del caballero. ${ }^{19}$ El barroco español coloca la pintura por encima de toda otra actividad artística;20 por eso el meditar es sólo "entallar" una imagen de madera y "perfilarla", mientras que el contemplar es pintarla. ${ }^{21}$ La meditación es como la actitud de quien se limitara a observar desde fuera un gran monumento ("ver el Escurial

8 Francisco de Osuna, Tercer abecedario espiritual, en Nueva Bibl. Aut. Esp., vol. XVI, Madrid, 1911, tratado XII, cap. v, pág. 457a.

9 Pedro de Alcántara, Tratado de la oración y meditación, citado en Arrigo Levasti, I mistici, Firenze, 1925, vol. II, pág. 94.

10 San Juan de la Cruz, Puntos de Amor, n 64, en Obras, ed. P. Bernardo de la Virgen del Carmen, 2 vols., Buenos Aires, 1942, vol. II, pág. 443.

11 ID., Subida del Monte Carmelo, libro II, cap. xIv, §7, vol. I, pág. 138.

12 Pedro de Alcántara, Tratado de la oración, vol. I, pág. 12, citado en Allison Peers, Spanish Mysticism, London, 1924, pág. 198.

13 San Juan de la CRuz, Subida, pág. 138.

14 Osuna, Tercer abecedario, trat. vI, cap. v, pág. 385b.

15 Ibid., trat. xil, cap. Iv, pág. 456b.

16 Santa Teresa, Las Moradas, libro iv, cap. II. Obras Completas, ed. de Luis Santullano, Madrid, 1940, pág. 347a-b.

17 Osuna, Abecedario, trat. I, cap. I, pág. 325a.

18 Santa Teresa, Las Moradas, lib. I, cap. II, pág. $325 \mathrm{a}$.

19 Osuna, Abecedario, trat. viII, cap. vir, pág. 414a.

$20 \mathrm{Cf}$. Hernrtat Wölfflin, Conceptos fundamentales en la historia del arte, Madrid, 1936, traducción de José Moreno Villa.

21 San JuAn de la CRuz, Llama de amor viva, iII, §57, vol. II, pág. 380. 
de espacio"), la contemplación es la obra creadora del artista: "trazar el Escurial y hacer los modelos". ${ }^{22}$ En términos de música-tan frecuentes en la novela pastoril - la meditación es "tañer con vihuela destemplada" y la contemplación "tañer con vihuela templada". ${ }^{23}$ En términos de artesanía, la meditación (o el alma en esa etapa) es sólo "un vaso de barro mal cocido" y la con. templación "un vaso de oro". ${ }^{24}$

Después de la relación entre efecto y causa, entre imperfección y perfección, nos encontramos ahora, en los autores españoles, con otra nueva, y la más importante: la relación entre una difícil actividad y una fácil pasividad. Se nos presentan, en primer lugar, pintorescas imágenes de esfuerzo y descanso, como el fatigoso "remar" y el suave "navegar engolfado" en que el viento es quien se encarga de hacer avanzar la nave; $; 5$ o bien el "romper la tierra", en contraste con el "aprovechar la simiente", que el labrador confía a la naturaleza. ${ }^{26}$ O se utiliza el "tirar el carro la cuesta arriba" 27 frente al tener "las ruedas de su carro untadas". ${ }^{28} \mathrm{O}$ el sacar uno mismo "el agua por los arca. duces" frente a "tener allegada el agua y beber sin trabajo"; 29 o el ponerse el hortelano a "sacar el agua y echar muchas veces el caldero en el pozo" frente a "llover... que lo riega el Señor sin trabajo ninguno nuestro". 30 Tomando como bases de comparación cosas de la vida cotidiana, la meditación es "quitar la corteza" de una fruta y la contemplación "gustar la sustancia". ${ }^{31}$ La una es un torpe andar infantil ("pateando al paso de niño"), la otra verse suavemente transportado en los brazos maternos (". . . sus madres llevarlos en brazos"); ${ }^{32}$ la una un infantil "sacar la leche con diligencia de su estrujar y manosear", la otra el rico alimento que el seno materno le ofrece generosa. mente ("recibiendo la leche en el pecho allegada y junta"). ${ }^{33}$ En fin, la meci 1 , tación corresponde a la empeñosa faena del gusano de seda al hilar su capulio ("con las boquillas van de sí mismos hilando la seda y hacen unos capuchillos"); la contemplación es el cambio pasivo del gusano en mariposa ("acaba este gusano y sale del mismo capucho una mariposica blanca muy graciosa") ${ }^{34} \mathrm{La}$ misma idea de Dante: Noi siam vermi/ Nati a formar l'angelica farfalla. ${ }^{35}$

22 Fray JuAn de los ANgeles, Lucha espiritual, parte I, cap. vil, en Nueva Bibl. Aut. Esp., Madrid, 1912, vol. I, pág. 295a.

23 Osuna, Abecedario, trat. XII, cap. vir, pág. $459 \mathrm{~b}$.

24 Ibid., trat. I, cap. II, pág. 326.

25 Bernardino de Laredo, Subida del monte Sión por la contemplación, libro m, cap. xL; cf. Gaston Etchegoyen, L'Amour divin, Essais sur les sources de Santa Teresa, Paris, 1923, pág. 228.

26 San JuAn de la Cruz, Subida, libro I, cap. viII, §4, vol. I, pág. 44.

27 ID., Avisos y sentencias, n 53, vol. II, pág. 431 .

28 Osuna, Abecedario, trat. XII, cap. v, pág. 458a.

29 San Juan de la Cruz, Subida, lib. il, cap. xiv, §2, vol. II, pág. 135.

30 Santa Teresa, Vida, cap. XI, págs. 38 y sig.

31 San Juan de la Cruz, Subida, lib. Il, cap. xiv, §3, vol. I, pág. 135.

32 Ibid., Prólogo, vol. I, pág. 8.

33 ID., Subida, lib. II, cap. XIV, §3, vol. I, pág. 135.

34 Moradas, lib. v, cap. II, pág. $358 \mathrm{a}$.

35 Purgatorio, $x, 124$ y sig. 
b) Francia: Racional y teórica, Francia no admite, como lo hace la práctica y pedagógica España, que la contemplación, gratia gratis data, pueda ser efecto místico normal, con la meditación ascética como causa. No hemos podido encontrar una sola comparación que conciba la meditación y la contemplación como causa y efecto, respectivamente. En cambio, hay muchos símiles que representan la relación imperfección-perfección. Pero lo que aquí sorprende en seguida es que los símiles franceses conciernen menos a lo francés que a lo humano en general. En esto son más precisos y exactos que los españoles.

La concepción barroca de San Francisco de Sales nos muestra cómo la visión total e instantánea de una bella corona ("regardant tous l'esmail d'une riche couronne d'une seule et simple veue") es visión más perfecta que la enumeración de sus pormenores ("voyant tous ses fleurons et toutes les pierres precieuses dont elle est composée"). ${ }^{36}$ De este modo el santo no sólo abarca la idea de imperfección-perfección, sino que también envuelve en su símil el carácter inferior, discursivo-analítico, de la meditación y el carácter superior, intuitivo-adivínatorio, de la contemplación. De la misma manera nos presenta la meditación como el aspirar el perfume de cada flor por separado (" $\mathrm{La}$ meditation est semblable a celuy qui odore l'oeillet, la rose, le romarin, le thym, le jasmin ... l'un après l'autre"), frente a la contemplación, que es como aspirar el perfume compuesto ("la contemplation est pareille à celuy qui odore l'eau de senteur composée de toutes ces fleurs"). ${ }^{37}$ Un tercer ejemplo de esta clase presenta la meditación como el mirar los muebles de un cuarto a oscuras encendiendo un candil y recorriendo la casa ("en battant le fusil, allumant la chandelle et regardant toutes ces choses") y la contemplación como un dejar entrar el sol y verlo todo de una vez ("sans peine et tout d'un coup") ${ }^{38}$ Los místicos franceses aluden con sus símiles a la contemplación en cuanto visión intuitiva y total, en contraste con la observación analítica. La meditación es también como la actitud que ante un cuadro asume el ignorante, a quien el pintor debe explicarle la belleza de la obra en todos sus pormenores ("apprendre d'un peintre par raisonnement"), mientras que la contemplación es la actitud del conocedor, que comprende el conjunto ("voit par une simple attention"). ${ }^{39}$ La comparación de Santa Teresa de la "gente en la ronda" y en el más "precioso lugar" gana también en precisión cuando se reemplaza con "servir en cuisine, en paneterie" para la meditación, y "servir en cabinet et conseil privé" 40 para la contemplación. Además de la mayor precisión intelectual en el concepto y la forma, los ejemplos franceses contienen un grano

36 San Francisco de Sales, Traité de l'Amour de Dieu, libro vi, cap.v, edición crítica de la Visitation d'Annecy, dirigida por Dom Mackey, 1892.1907, 22 vols,, vol. Iv (I) y v (II). I, pág. 303.

37 Ibid., libro vI, cap. v, vol. I, pág. 319.

38 JeAn de Barnières-Louvigny, Le chrétién intérieur, en Henri Bremond, Histoire littéraire du sentiment religieux en France. Paris, 1916-1933, 11 vols., vol. vI, pág. 232.

39 San Juan Bautista de la Salle (1651-1719), Exercice de la présence de Dieu, citado en P. Pourrat, La spiritualité chrétienne, vol. iv, pág. 395.

40 San Francisco de Sales, Introduction à la vie dévote, ed. Ch. Forot, Paris, 1934, pág. 115. 
de espíritu crítico; así, la meditación la vemos comparada en Lallemant con el acto de ver un león pintado, y la contemplación con el de ver un león vivo $^{41}$; y en Pierre de Bérulle la meditación con la reposada medición científica del sol ("se donner loisir de mesurer la grandeur et les dimensions de ce grand astre par les règles de l'astronomie") y la contemplación con el pasmo y arrobo del hombre que, habiendo estado preso toda su vida en una oscura caverna, sale de ella ("sortant d'une caverne et obscurité profonde") y mira por primera vez la belleza del sol resplandeciente ("en la sérénité d"un beau jour") ${ }^{42} \mathrm{Si}$ consideramos la comparación que hace Miguel de Molinos - y cuya pobreza le reprocha Bossuet - 43 de la meditación como un viajar repasando constantemente el itinerario y la contemplación como un viajar con el itinerario bien sabido, entonces el paralelo francés de Lagny parece más elegante y acertado. Lagny presenta la meditación como el conocimiento de un idioma por reglas ("toutes les règles particulières") y la contemplación como el conocimiento de un idioma por práctica ("une parfaite habitude de mettre les règles en pratique"). ${ }^{44}$

Entre las imágenes que expresan difícil actividad y fácil pasividad, los escritores franceses toman de los símiles españoles los tres conceptos fundamentales de la navegación a remo y a vela, del difícil y fácil comer y del marchar y descansar. Pero adornan este tema con variaciones francesas. Para la navegación a remo y a vela el obispo Camus evoca las galeras del rey y llama a la meditación une galère à la rame y a la contemplación une galère à la volle. ${ }^{45}$ El jesuíta Lallemant utiliza imágenes aún más gráficas. La meditación es "une chaloupe qu'on fait aller à force de rames avec bien du travail et de bruit et lentement", y la contemplación "un navire qui vogue à pleines voiles, le vent en poupe". ${ }^{46}$ En este ejemplo el afán de claridad destaca otro aspecto de las dos formas de la vida religiosa y la oración; en un caso ejercicio ascético ("force"), labor empeñosa ("travail", "bruit"), avance paulatino ("lentement"); en el otro la ayuda divina ("le vent en poupe") y un avanzar prodigiosamente ("à pleines voiles"). En verdad, "ce qui n'est pas clair n'est pas français". Mientras que San Juan de la Cruz se satisface con vagas analogías como la de meditación = "masticar la comida", contemplación ="gustar la comida", 47 San Francisco de Sales opone al trabajoso masticar ("en méditant on masche") el refrescante heber ("boire c'est contempler, et cela se fait sans peyne, ni résistance, avec plaisir et coulamment"). ${ }^{48}$ La claridad francesa llega

41 P. JEAN Rigoleuc (ed.), La vie et la doctrine spirituelle de Louis Lallement, Paris, 1694. Edición alemana, Freiburg, 1921, pág. 203.

42 Claude Taveau, Le Cardinal de Bérulle, maître de vie spirituelle, Paris, 1933, pág. 81 .

43 Bossuet, Instructions sur les états d'oraison, Paris, 1697, pág. 124.

44 PAUL DE LAGNX, Le chemin abrégé de la perfection chrétienne, citado en Henri Bremond, Histoire littéraire, vol. via, pág. 274 y sig.

45 Pierre Camus $(1582 \cdot 1653)$, La théologie mystique, Paris, 1640, pág. 276.

46 Louis Lalinmant, citado en Pourrat, vol. IV, pág. 73.

47 Subida, lib. II, cap. XIv, \$7, pág. 138.

48 Amour de Dieu, libro vi, cap. vi, vol. I, pág. 325. 
al máximo al simbolizar la alimentación "meditativa" con la imagen de un niño que recibe la leche en una cuchara ("en une cuiller ou autre instrument"), y la contemplativa con la del niño que recibe "le sein dans la bouche... en sorte que cette substance maternelle serve de tuyau aussi bien que de nourriture". ${ }^{49}$ Una vez más la comparación está llena de implicaciones: el aspecto mís. tico de la contemplación interesa tanto al modo como al objeto de la experiencia divina. El símil español del marchar y descansar recibe en Francia un minucioso desarrollo, en cuatro fases. Ante todo, al difícil y laborioso caminar no se le opone precisamente el descansar, sino un fácil y suave vuelo, sin estorbo alguno..$^{50}$ En segundo lugar, la imagen del camino a pie se conserva tanto para la meditación como para la contemplación, pero la una es un caminar entre zarzas y malezas ("dans un labyrinthe inextricable"), la otra el fácil caminar por un llano, despojado el viajero de las ropas que le molestaban ("dans un fort beau chemin et tout nu pour aller plus vite"). ${ }^{51}$ La tercera comparación mantiene la imagen del descanso para la contemplación, pero introduciendo para la meditación la imagen de las abejas que recogen la miel ("piller les fleurs") y descansan en la colmena ("elles se tiennent sur leurs rayons")..$^{52}$ La cuarta variante vuelve directamente al viejo esquema de marchar y descansar, pero con una especificación, la del centinela que unas veces echa a andar a grandes pasos ("agit des pieds et des mains") y otras se queda en su garita o en un rincón de la fortaleza ("une sentinelle dans une guérite ou quelque coin de empart, assise ou appuyée"). ${ }^{53}$ Símil tan elaborado quizá recuerde, para el lector superficial, ese libre desarrollo conversacional de las comparaciones en Santa Teresa (el riego del jardín, el gusano de seda). Pero la manera francesa de Camus dista mucho de ser una conversación; es un verdadero símil homérico en que se elabora la implicación de que la quietud contemplativa no es el quietismo de la indi. ferencia, sino un velar con ayuda divina, para lo cual sólo hacen falta ojos atentos ("seulement des yeux qui regardent par tout ... pour éviter une surprise; . . . action paisible, tranquille, réposée"), no las zancadas del centinela.

\section{PREPARATIVOS PARA LA CONTEMPLACIÓN}

\section{(PURGACION, DESASIMIENTO, RECOGIMIENTO)}

a) EsPaña: De acuerdo con su idea ascética fundamental de que el ir venciendo las imperfecciones es la causa de la perfección final de la contemplación, los españoles dan especial importancia, en sus símiles acerca de la

49 Ibid., libro III, cap. Ix, vol. I, pág. 210.

50 Allan G. McDougall (ed.), The Spiritual Doctrine of Fr. Louis Lallemant, S.J., Westminster, Maryland, 1946, pág. 258.

51 Emile Dermenghem, La vie admirable et les révélations de Marie de Vallées. D'après des textes inédits, Paris, 1926, pág. 243.

52 Camus, Théologie mystique, pág. 179.

53 Ibid,, pág. 192. 
preparación mística, a id taxea de purgar toda imperfección, hasta donde sea posible para el hombre. Mortificación y lágrimas son comparables con la lluvia abundante que limpia el cielo "turbio y escuro", de suerte que "paresce reírse mostrando su hermosura". ${ }^{4}$ Debemos tratar estas imperfecciones como quien limpia un mantel manchado:

El paño que está muy sucio has de lavar mucho y estregar mucho, y jabonallo mucho para que quede blanco y pueda servir a la mesa. Pero mira, que si se jabona con agua fría no saldrán las manchas viejas y que están muy encorporadas y empapadas en el paño ....; menester es hacer una colada de lejía y echalla hirviendo sobre [ellas]. ${ }^{55}$

El objeto de esta inexorable limpieza en la "noche oscura de los sentidos" es una liberación, un desasimiento en que el alma es como un pájaro, primero cazado con liga, pero luego liberado y limpio ("dos veces trabaja el pájaro que asentó en la liga, es a saber: en desasirse, y limpiarse de ella"). ${ }^{56}$ Los místicos españoles explican muy claramente este doble aspecto del penoso y purificador desasimiento con el símil de las serpientes que "después deste remojar su piel en algún río entran por algún angosto y áspero lugar para dejar la vieja vestidu. ra." 57 También aquí se nos presentan siempre como inseparables los medios ascéticos y el fin místico. El recogimiento y la quietud son la meta del proceso.

Por eso la última etapa del desasimiento, que lleva a la quietud del recogimiento, no pertenece al hombre sino a Dios, el cual no desdeña medios radicales. Este aspecto final se compara con el golpear a unos muchachos en la cabeza para hacerlos entrar en razón ("el que para castigo de aquestos mochachos les diese de cabezadas a estas piedras, harálos asesar"); 58 o con el domesticar a unas aves silvestres ("avezar a estar en la jaula") ${ }^{59}$ o con el vendar al gavilán para dirigirlo hacia su presa ("el gavilán los ojos descubiertos nunca tiene en reposo y por eso dévenle cuvrir los ojos para que aprenda a volar solamente a la prea que le conviene") $;{ }^{60}$ o con el quemarle las alas a una inquieta mariposa ("A esta mariposilla importuna aquí se le queman las alas, ya no puede más bullir"); ${ }^{61}$ o con el peinar el cabello desde arriba, aun cuando lastime, a fin de embellecerlo ("El cabello se comienza a peinar de lo alto de la cabeza si queremos que esté esclarecido"). ${ }^{62}$ Los místicos españoles, famosos por su análisis del proceso místico, conciben también la quietud como un graduado amortiguamiento de la voluntad, del entendimiento y da la memoria, proceso comparado por ellos a un clavarse en la cruz con tres clavos. ${ }^{63}$

54 Osuna, Abecedario, trat.x, cap. II, pág. 433a.

55 Fray Pedro Malón de Chaide, La conversión de la Madalena, §38, Bibl. Aut. Esp., xxVII: Escritores del siglo XVI, pág. 364a.

56 San Juan de la Cruz, Avisos y sentencias, n²2, vol. Ir, pág. 437.

57 Abecedario, trat. Ix, cap. II, pág. $418 \mathrm{a}$.

58 Ibid., trat. Ix, cap. II, pág. 420 a.

59 Ibid., trat. Ix, cap. IV, pág. 422 b.

60 Ibid., trat. IV, cap. L, pág. $357 a-b$.

61 Santa Teresa, Vida, cap. xviII, pág. 67a.

62 Puntos de Amor, n²6, pág. 437.

63 Abecedario, trat. $x$, cap. vII, pág. $440 b$. 
b) Francia: Los místicos franceses insisten en la famosa fórmula del "laisser faire", tan frecuentemente comentada por el abate Bremond; no confían en la posibilidad de expresar su purificación y desasimiento en aserciones positivas. El utilizar la fórmula negativa de "ne pas faire" en vez de "faire" tiene algo que ver con la mesura francesa, que en el proceso de desasimiento aparece unas veces en el concepto y otras en la forma, aunque la expresión externa puede ser sumamente enérgica y realista. Mientras que los españoles abundan en suspiros y lágrimas, los franceses insisten en "ne jamais se plain. dre", es decir, en no ceder a la propia voluntad. No es poco; es tanto como el perinde cadaver de San Ignacio. El alma que trata de llegar al desasimiento procede como "la boue et la ballieure qui se laisse piler et repiler des pieds des maîtres et des valets". 64 Es típico de esta actitud negativa, y también del ideal francés tradicional del pequeño propietario, el comparar el desasimiento con el dejar de ser "propriétaire de créatures", 65 o de sí mismo ("les âmes propriétaires d'elles-mêmes") ${ }^{66}$ En Aumont encontramos el símil, que ya hemos visto en Osuna, de la serpiente que muda su piel, elaborado con más extensión y a la manera homérica: nos muestra con muchos y claros pormenores las etapas graduadas del proceso ("peu à peu, premièrement, à la mesure, enfin, achever"):

On dit qu'il y a une saison . . . en laquelle les couleuvres se dépouillent de leur vieille peau, et pour ce faire, elles choisissent un lieu étroit et fort serré, comme entre deux pierres de roche, ou entre deux fortes épines, en quelque buisson, et passant ainsi à force, elles commencent à se dépouiller premièrement la tête, en coulant peu à peu; à mesure leur peau se dépouille, et enfin, achevant de passer par la queue, elles laissent leur vieille peau derrière elles. ${ }^{67}$

Una vez más un tremendo "dépouillement" expresado con dulzura y gracia. Lo mismo se expresa mediante la imagen del poner uno sus vestidos a los pies del Señor, como recordando el histórico rasgo de San Francisco de Asís en presencia del obispo ("mettre aux pieds de Notre Seigneur tous ses vetêmentes, l'un après l'autre, le suppliant de les garder") ${ }^{68}$ o con la de caminar de puntillas ("marcher sur la pointe"), ${ }^{69}$ es decir, sin hacer ruido, penetrando en el silencioso reino dc Dios; o con la del pichoncillo implume que, por serlo, puede ocultarse bajo las alas maternas ("Comme un petit oiseau tout déplumé se cacher et se musser sous l'aile de sa bonne mère"). ${ }^{70}$

64 JEAN DE BERnIEREs, Le Chretien intérieur ou la conformité intérieure que doivent avoir les Chretiens avec Jésus-Christ, tiré des manuscripts de feu de sainte mémoire Mr. Jean de Bernières-Louvigny, autrefois trésorier de France du bureau de Caen, par le P. Louis-François d'Argentan, Rouen, 2 vols., 1677, vol. II, pág. 55.

65 Ibid., vol. Ir, pág. 53.

66 JEAn Aumont, L'ouverture intérieure du royaume de l'Agneau occis dans nos coeurs, 1666, citado en BrEMOND, Histoire littéraire, vol. vir, pág. 348 .

67 Ibid., pág. 349.

68 Sainte Jeanne Françoise de Chantal, Oeuvres complètes, 7 vols., Paris, 1877.1893 , vol. 1I, pág. 8 .

69 Ibid., vol. II, pág. 427.

$70 \mathrm{Ibid}$., vol. II, pág. 499. 
La más austera doctrina de San Juan de la Cruz, la del absoluto, radical y penoso desasimiento de todo, recibe en francés un sesgo intelectual con que las implicaciones morales resultan suavizadas y el desasimiento se convierte más en problema racional que ascético, como lo sugiere el símil casi cartesiano de "un vrai philosophe [qui] n'agit que par la force de la raison et tâche d'éttouffer cet instinct naturel qui le fait ressembler aux bêtes".71 Muy de acuerdo con las tendencias del humanismo francés, el recogimiento puede aprenderse de los antiguos, quienes en sus fiestas se ceñían las sienes con guirnaldas a fin de que no llegaran a perturbar su espíritu los ruidos exteriores:

Les anciens avaient accoutumé de se serrer le front en leurs festins avec des bandeaux tissus de fleurs et d'herbes odorantes pour se conserver la raison plus libre et se garantir de l'étourdissement et mal de tête que leur pouvait causer le bruit de telles assemblées. ${ }^{72}$

\section{III}

\section{EFECTO DE LA CONTEMPLACIÓN INFUSA: QUIETUD}

a) Espa ÑA : El efecto de la contemplación infusa aparece en los místicos españoles en dos géneros de símiles: unos describen el hecho y otros el sentimiento. Una nueva distinción cabe hacer entre la etapa inceptiva fundamental (con la sorpresa consiguiente) y el cambio progresivo del hecho y del sentimiento correspondiente.

El símil tradicional del hierro atraído por el imán, que Santa Teresa cambia por el de "una paja cuando la levanta el ámbar" "3, es la imagen más acabada de ese hecho prodigioso de que el alma aquietada sea movida por Dios. Él modela al alma "como gota de vinagre que cava la tierra"; 74 Dios, el cazador, la ha perseguido y herido: "El dulce cazador [la] tiró y dejó rendida." 75 Es exclusivo mérito de los españoles haber especificado la decreciente actividad de las facultades por obra de su unificación y creciente pasividad en la con. templación con símiles tan eficaces como los creados por Santa Teresa: Las almas contemplativas empiezan por ser "asnillos para traer la noria del agua... cerrados los ojos y no entendiendo lo que hacen". 76 Entonces se abandonan por entero a la misericordiosa obra de Dios, "no como los que están en el cadalso mirando al toro [sino como] los que andan poniéndosele en los cuer. nos". ${ }^{77}$ Acabàn por no ser más "que la cera cuando imprime otro el sello... sólo está dispuesta, digo blanda; y aun para esta disposición tampoco se

71 P. Hercule Audiffret, Ouvrages de piété, en Bremond, Histoire littéraire, vol. vir, pág. 195.

72 Pére Joseph (Françols Leclero de Tremblay), Discours de la perfection séraphique, Paris, 1934, en Louss Dedouvres, Le Pire Joseph. Etudes critiques sur ses oeuvres spirituelles, Paris, 1903, pág. 147.

73 Moradas, lib. v1, cap. v, pág. 384a.

74 Abecedario, trat. X1, cap. 1V, pág. $446 \mathrm{~b}$.

75 Santa Teresa, Poesías, pág. 642b.

76 ID., Vida, cap. xx1r, pág. $87 b$.

77 ID., Camino de perfección, cap. Xxxix, pág. $315 \mathrm{a}$. 
ablanda ella, sino que se está queda y lo consiente".78 Este hallazgo del progreso en la contemplación como graduado y mensurable es uno de los grandes triunfos del "ensimismarse" español. También San Juan de la Cruz sorprende el alma en su camino hacia la plenitud de la contemplación, aunque, usando el mismo símil tradicional del "sello en cera", expresa una etapa anterior a la de Santa Teresa: "el alma sintiéndose estar como la cera que comenzó a recibir la impresión del sello y no se acabó de figurar".79

Las afirmaciones generales y más vagas acerca de la quietud de la contemplación se refieren siempre a un proceso lento y paulatino que va comple. tándose más y más. Por esto los españoles dicen que el hombre desnudo está vestido; 80 que al niño lo toman en los brazos maternos, lo besan, amamantan y acarician ("Abre la madre sus brazos al niño y allende de lo abrazar, ábrele sus pechos e junta su rostro con el de su hijo"); 81 que las manos temblorosas que sostienen el vaso colmado se van serenando cada vez más, de modo que el vaso "puede ser lleno sin se derramar". 82

Al lado de esta descripción progresiva de la quietud mediante símiles, hay también excelentes comparaciones de los estados inceptivo y final. Aquí la exactitud de la imagen resulta todavía más asombrosa. En el estado inceptivo de quietud, el alma tiene la experiencia del "ojo que cayendo se va sabrosamente al sueño ciego", 83 o la de quien, después de velar toda la noche, se ve agradablemente sorprendido por la aurora. ${ }^{84} \mathrm{La}$ súbita conciencia del estado de quietud contemplativa es como descubrir el fluir del "agua viva que está debajo del yelo muerto", 85 o como "el pollo que bive dentro del huevo sin lo haver horadado", 86 o "como si echasen en los tuétanos una unción suavísima a manera de un gran olor . . que nos penetra todos", 87 o como una especie de olor de incienso que viene súbitamente del oculto lugar donde se está quemando ("una fragancia como si . . estuviese un brasero adonde se echasen olorosos perfumes: ni se ve la lumbre, ni donde está"). ${ }^{88}$ Francisco de Osuna llega hasta describir el momento mismo en que el asceta pasa a ser místico, en que es invadido por Dios:

Viene algún pensamiento al corazón y se detiene de forma que antes que el hombre conozca lo que era es alanzado, como si dende lejos dijésemos a alguno que no se acercase; mas antes que lo conosciésemos, pasa esto tan cierto en el ánima que el mesmo hombre se maravilla de ello. ${ }^{89}$

78 ID., Moradas, lib. v, cap. II, pág. 361 b.

79 Cántico espiritual, canción XI, pág. 83.

80 Puntos de Amor, n. 19, vol. II, pág. 436.

81 Abecedario, trat. I, cap. I, pág. $323 \mathrm{~b}$.

82 Ibid., trat. IV, cap. v, pág. 364 b.

83 JUAN DE LOS ÁNGELES, Lucha espiritual, vol. I, pág. XII.

84 Abecedario, trat. XI, cap. IV, pág. 447a.

85 Ibid., trat. xill, cap. IV, pág. 469a.

86 Ibid., trat. xm, cap. Iv, pág. 469a.

87 Santa Teresa, Conceptos del amor de Dios, cap. IV, pág. 439 b.

88 ID., Las Moradas, lib. Iv, cap. II, pág. 348a.

89 Abecedario, trat. xxI, cap. vil, pág. $571 \mathrm{a}-\mathrm{b}$. 
El estado final de quietud cobra también una determinada significación a la luz de la purgatio que le ha precedido. De ahí símiles como el que compara la quietud final con una casa que se ha despojado para recibir los tesoros del Rey ("sólo queda el casco de la casa vacío, porque el rey trae consigo lo que es necesario")..$^{90}$ El famoso paralelo de San Juan de la Cruz: "Estando ya mi casa sosegada" 91 adquiere para el lector nueva importancia desde que Yakov Malkiel ha señalado en la palabra sosegar las connotaciones del lat. sub. secare, de donde casi seguramente procede; es decir: segar, cercenar, cortar, castrar, mutilar, quitar fuerza vital, ${ }^{92} \mathrm{y}$, en el caso del alma, aquietarla hasta borrar de ella el último elemento de egocentrismo. El alma totalmente aquietada no es sólo el "asnillo traendo la noria", sino la "bestiula en que va el Señor a Hierusalem";93 que corresponde no sólo a "la aurora de la mañana", sino a "el alba ... clarificada [que] deja de ser aurora".94 El alma desfallecida y exhausta por el largo proceso de la purificación, ya incapaz de moverse por sí misma, se encuentra al fin yaciendo "como el enfermo que actualmente está en la cama con fiebre o cición muy recia [que] siempre se conoce atado".95 Todos los ruidos del antes bullicioso molino, como el de "martillo", "sierra", "cosa de hierro", "estruendo dañoso", han cesado definitivamente. 96 La nave, mar adentro, ya es incapaz de cambiar su curso ("como nave que está muy metida en el mar, que aunqrie ella quiera, no puede un poquito declinar acá ni allá").$^{97}$

b) Francia: Los símiles franceses para la quietud mística llaman la atención ante todo porque eluden la explicación dinámica del progreso en la contemplación, cuya observación metódica aprendieron los españoles de los árabes. ${ }^{98}$ La mesura francesa considera precisamente esta observación metódica como curiosité; lo dice con toda claridad la ursulina Marie de l'Incarnation: "Je ne me mets point en peine de faire tant d'examens, mais plutôt j'y sens l'aversion, crainte de curiosité".99 Prefiere subrayar más bien el hecho de que en toda forma de quietud y pasividad (excepto, desde luego, el pleno éxtasis), hay siempre cierto grado, por pequeño que sea, de cooperación humana. Por esto las almas en quietud se comparan con ríos de lento curso ("certains fleuves qui coulent si doucement et si également") que aparecen ante quien los mira

90 Abecedario, trat. Iv, cap. v, pág. 364a.

91 San Juan de la Cruz, Subida, lib. I, cap. I, pág. 13.

92 Yaxov Malkiel, The Etymology of Spanish "sosiego", en PhQ, xxirr, 1944, pág. 304.

93 Abecedario, trat. XxI, cap. v, pág. 506b.

94 JuAN de los Ángeles, Vida perfecta, diálogo Iv, vol. I, pág. 218 b.

95 ID., Lucha espiritual, parte II, cap. III, vol. I, pág. 324b.

96 Abecedario, trat. III, cap. III, pág. 352a.

97 Bernardino de Laredo, Subida del monte Sión, cap. III, en Gaston Etcher goyen, L'amour divin, Paris, 1923, pág. 228.

98 Miguel Asín Palacios, La espiritualidad de Algazel y su sentido cristiano, Madrid, 1939, vol. III, pág. 155.

99 Marie de L'Incarnation, Ecrits spirituels et historiques, ed. de Dom Albert Jamet, Paris-Québec, 1929 y sigs., vol. II, pág. 157. 
desde la orilla como lagos estancados porque no se percibe la agitación de sus aguas, ${ }^{100}$ o con las estrellas que giran alrededor del polo tan lentamente que apenas se puede advertir que se mueven. ${ }^{101}$

El antiguo símil del imán que atrae al hierro se modifica en los escritores franceses en el sentido de que el hierro se hace más activo, llega a ponerse trémulo, deseoso de acercarse al imán:

Le fer a une telle convenance avec l'aymant qu'aussitôt qu'il en apperçoit la vertu, il se retourne devers luy, puis il commence soudain à se remuer et demeurer par des petits tressaillements, tesmoignant en cela la complaisance qu'il ressent, en suite de laquelle il s'avance et se porte vers 1'aymant. ${ }^{102}$

El ejemplo español del niño a quien su madre toma en brazos y lo besa, amamanta y acaricia aparece en francés transformado en la misma dirección: también el niño hace algo, no sólo la madre. Tan pronto como la madre le of rece el pecho, él procura acercársele y empieza a patalear, deseoso de recibir la leche:

L'enfançon fait des petits élans du costé des tétins da sa mère et trépigne d'ayse de les voir descouverts, comme la mère aussi de son costé les luy présente avec un amour empressé. ${ }^{103}$

El concepto activo de laisser faire asoma a través de las imágenes francesas, que precisamente destacan la pasiva invasión de quietud, como lo prueba el siguiente símil, en que el niño hace nada menos ("sans avoir fait [!] autre chose") que quedarse quieto, mientras su madre lo viste:

Une mère par son action propre revêt et habille son enfant qui, sans avoir fait autre chose que de laisser agir sa mère, se trouve tout habillé. ${ }^{104}$

Los escritores franceses, como es natural, no pueden descartar el "milagro" de la quietud inceptiva en sus efectos sobre aquel a quien se ha concedido esa experiencia mística. Pero es de sumo interés la comparación del doble símil de Osuna (el del pensamiento que surge inesperadamente y el del extraño que se acerca y a quien no es posible alejar) con los de San Francisco de Sales (el del hombre adormilado que oye hablar a sus amigos o el del que siente que lo acarician). Porque mientras Osuna trata de aclarar lo extraño de este sen. timiento, San Francisco de Sales quiere subrayar que la acabada concentración del alma en Dios hace imposible una más clara concentración en sí misma ("surpris d'un léger sommeil nous entendons sans distinguer ce que nos amis disent autour de nous ou nous ressentons les caresses qu'ils nous donnent,

100 San Francisco de Sales, Amour de Dieu, lib. vi, cap. vili, vol. i, pág. 330.

101 Camus, Théologie mystique, pág. 198.

102 Amour de Dieu, vol. I, pág. 42.

103 Ibid., lib. v, cap. II, vol. II, pág. 260.

104 P. François GuIlloré, S. J., Maximes spirituelles, 1684, citado en BREMOND, Introduction à la philosophie de la prière. Textes choisis, Paris, 1929, pág. 256. 
presque imperceptiblement, sans sentir que nous sentons"). ${ }^{105}$ Sin embargo, los franceses atienden tanto como los españoles al elemento de la sorpresa en la primera invasión del alma por la quietud divina. Y la expresan con el símil de la inesperada desviación de un río por la rotura de un dique: "Cette paix vient comme un fleuve dont le cours est détourné . . par la rupture d'une chaussée". ${ }^{106} \mathrm{O}$ bien con el de la súbita comprobación de que se está saboreando vino cuando se esperaba beber agua, como en las bodas de Caná: "[L'âme] s'apperçoit qu'on fait des noces en son coeur et que l'eau froide et insipide est changé en un vin délicieux". 107

Un símil muy poco usual, típico del clasicismo francés, es el de la inspi' ración que se infunde en el alma de los poetas antiguos, como se explica —-según el jesuíta Surin - en aquel pasaje de la décima Oda de Ronsard, dedicada a Michel de l'Hôpital, en que Júpiter dice al poeta:

\section{Lorsque la mienne (vertu) ravissante \\ Vous viendra troubler vivement, \\ D'une poitrine obéissante \\ Tremblez dessous son mouvement.}

"Estos versos - continúa Surin - parecen escritos para expresar . . . lo que el espíritu de Nuestro Señor obra en las almas." 108 Este curioso paralelismo no lo ha advertido Henri Bremond en su propio ensayo sobre Prière et poésie. El humanista francés halla un serio competidor en el aldeano "et vigneron de Montmorency" Jean Aumont. Aumont se refiere cos estas imágenes a la quie, tud inceptiva: "la criada, desde la guardilla, oye de pronto que alguien golpea desde dentro del sótano, y ella, llena de susto, pregunta desde lo alto de la casa: ¿Quién anda ahí? ${ }^{109}$ Este símil es casi un rapport fatal. Pues el extraño que golpea es Dios en los sótanos del corazón, "le sanctuaire du coeur". Más común es la comparación del ciego que se siente sorprendido cuando lo toca alguien a quien él no ve y "cet attouchement . . . tient lieu de connaisance à l'aveugle". 110

Además, los místicos franceses presentan también la quietud inceptiva con símiles que muestran el alma en su retorno de la "oración de quietud" a la "normalidad", con lo cual descubre qué tesoro había poseído. La situación es entonces la del niño que se queda dormido mientras bebe del pecho materno, que aún conserva entre los labios. Pero cuando la madre vuelve a poner al

105 Amour de Dieu, lib. vi, cap. vilr, vol. I, pág. 331.

106 P. Jean Joseph Surin, S. J., Questions importantes sur l'amour de Dieu, lib. III, cap. II, en H. Bremond y CH. Grolleau, Anthologie des écrivains catholiques, Paris, 1919 , pág. 144.

107 Pére J. Crasset, S. J., Le Chrétien en solitude, en Bremond, Histoire littéraire, vol. viII, pág. 293.

108 Surin, Lettres spirituelles, vol. II (Science expérimentale), Paris, 1663, pág. 82.

109 Jean Aumont $(1609 \cdot 1689)$, L'ouverture intérieure du royaume de l'Agneau occis dans nos coeurs, en BREMOND, Histoire littéraire, vol. viI, pág. 332.

110 Jean Baptiste Noulleau $(1604 \cdot 1672)$, L'idée du vrai chrétien, en Bremond, Histoire littéraire, vol. viI, pág. 249. 
niño en la cuna, él empieza a llorar desesperadamente, echando de menos alimento y protección "parce que dormant pour toute autre chose, il veilloit pour celle-là seule de presser la mammelle et d'en tirer sa douce nourriture". ${ }^{111}$

El estado final de quietud representado como un fait accompli se expresa por símiles que hasta cierto punto también encontrábamos en los españoles. Pero los franceses están, desde un punto de vista metafisico, más cargados de sentido. En primer término, el símil de la cera en que Dios ha impreso su sello. La nation d'écrivains cambia la cera por el papel blanco - ¡la obsesión de Mallarmé!-: "une charte blanche" en que alguien (Dios) está escribiendo "tout ce qui lui plairait". 112 También encontramos la imagen de un hombre atado ("un homme attaché à un arbre avec une corde") puesto luego en libertad por obra divina, ${ }^{113}$ o al revés, la de un hombre libre luego atado (por obra divina) "à ce poteau où vous demeuriez immobile". ${ }^{114}$ También aparece en francés la "casa sosegada", pero bajo forma de una casa saqueada y vaciada por los ladrones, de suerte que el dueño bien puede compararse con Diógenes:

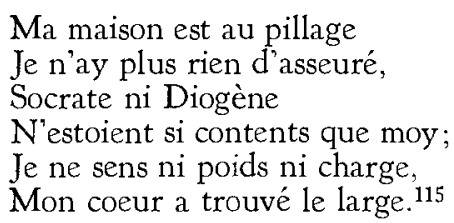

Más típicamente francés que las huellas del "humanismo cristiano" es también aquí el espíritu de pequeño propietario, que se traduce en la comparación del alma aquietada con "une terre vendue". 116 Hay otras imágenes para el mismo estado de quietud, tomadas de distintos oficios: una venda puesta sobre los ojos; $; 17$ una esencia líquida que se mantiene quieta en el alambique porque

Il n'est pas possible de tirer l'essence d'une chose mobile, mais il faut que la matière demeure dans l'alambic . . . ramassée et renfermé ...., immobile ... pour y être essentiée; ${ }^{118}$

111 Camus, Théologie mystique, pág. 212. El mismo símil, menos desarrollado, en San Francisco de Sales, Amour de Dieu, vol. I, pág. 332.

112 CRasset, La foi victorieuse, en Bremond, Histoire littéraire, vol, vili, pág. 292.

113 San Vicente de Paul, Correspondance, Entretiens, Documents, ed. Pierre Corte, Paris, 1923, vol. X, pág. 162.

114 Surin, Lettre à Madeleine Boinet, en Pourrat, Spiritualité chrétienne, vol. Iv, pág. 145.

115 ID, Cantiques spirituels de l'Amour divin. Composez par un Père de la Com. pagnie de Jésus, Paris, 1664 , pág. 50.

116 Alexander Piny, O. P., L'état du pur amour, en Bremond, Histoire littéraire, vol. viII, pág. 130 .

117 Santa Margarita María Alacoque, Vie et oeuvres, ed. Msgr. Gauthey, Paris, 1915, vol. II, pág. 335 . 335.

118 Aumont, L'Ouverture intérieure, en BrEmond, Histoire littéraire, vol. vil, pág. 
finalmente, el perfecto mecanismo de un reloj ("perfectionner ce que les roues d'horloge sont à la montre"). ${ }^{119}$

Los franceses, como moralistes, en el proceso de aquietamiento dan importancia abrumadora a la Gracia - como si dijésemos, Jansenio contra Molina- pues, a despecho de todas las purificaciones, las almas siguen siendo indignas de ella. Por esto se las compara con unas malolientes bestias de carga que llevan muebles principescos: "Les mulets laissent-ils d'être lourdes et puantes bêtes pour être chargés des meubles précieux et parfumés du prince?" ${ }^{20}$ Las almas están siempre en peligro de ser unos sucios vasos ("un vaisseau qui sent mauvais") que echan a perder el agua limpia ("l'eau nette et claire") que contienen; o toneles que aún conservan restos de mal vino ("un tonneau dont l'intérieur est gâté par un autre vin"), de tal modo que el nuevo vino que se vierte en él se echa a perder a su vez, puesto que "el agua clara y el buen vino toman fácilmente su mal olor". ${ }^{121}$ Estas consideraciones nos llevan a examinar ahora los símiles referentes a las purgaciones pasivas.

\section{IV}

\section{PURGACIONES PASIVAS}

a) España: Para la purgación pasiva, que limpia más y más las almas y las lleva a la unión mística, San Juan de la Cruz ha creado uno de los símbolos más profundos, "la noche oscura del alma", punto de que trato de. tenidamente en otro lugar. ${ }^{122}$ Pero este símbolo multilateral arroja mucha luz sobre la unilateralidad de cada uno de los otros símiles místicos españoles, ninguno de los cuales abarca todas las implicaciones de ese "purgatorio en la tierra". Los españoles consideran el dolor que limpia y pule las almas, o como un dolor lleno de esperanza, o como dolor que engaña y tortura, o como ansia penosa y expectante. Los símiles utilizados para expresar estas experiencias subrayan el aspecto objetivo, el fisiológico o el psicológico. En cuanto al dolor que pule, Dios aparece como artesano que, antes de acudir a sus herramientas más afiladas, empieza por acepillar la obra en grueso: "Dios sea como el polido tornero que no pone sus sotiles herramientas sino en lo que primero está labrado de azuela". ${ }^{23}$ El símil que Osuna utiliza para la purgación activa -el del lavado de ropa-, lo afina San Juan de la Cruz agregando el detalle de las manchas antiguas y casi invisibles en un paño, que salen al segundo lavado, con

119 JeAn Huguts QuarŔ, Trésor spirituel, en BREMOND, Introduction à la philo. sophie de la prière, Paris, 1929, pág. 243.

120 Amour de Dieu, lib. III, cap. v, vol. I, pág. 126.

$121 \mathrm{~L}$. Grignon De Montrort, Traité de la vraie dévotion à la très Sainte Vierge ou Le secret de Marie, Sheerbrook, Canada, 1901, pág. 52.

122 The infuence of Ramon Lull and Jan van Ruysbroeck on the Language of the Spanish Mystics, en Traditio, Iv, 1946, págs. 332-392; sobre la noche oscura, cf. págs. $365 \cdot 374$.

123 Abecedario, trat. XI, cap. vI, pág. $450 \mathrm{a}$. 
"jabón y fuerte lejía". ${ }^{24}$ Esta enérgica limpieza quita las manchas "como hace el fuego al orín y moho del metal". ${ }^{125} \mathrm{O}$ imaginemos una mujer que, pensando que el agua que tiene en una vasija está limpia y clara, de pronto, a la luz del sol, ve "que está todo de motas", y la llena de desesperación el no poder limpiar debidamente la vasija ("Aquí no sólo las telarañas ve de su alma, sino un polvito que haya, $y$ por mucho que trabaje en perfeccionarse, toda se ve turbia"). 126

El último ejemplo traduce muy claramente la idea, fundamental para los místicos, de que el alma, mientras avanza, reconoce cada vez más su humilde condición de criatura frente a las altas gracias que se le han otorgado, y se siente desesperadamente desvalida. Porque, sin la ayuda de Dios, no puede purificarse a sí misma. Su desolada situación se trasluce ahora en los símiles que expresan ese martirio de impotente prisionero:

Como el que tienen aprisionado en una oscura mazmorra atado de pies y manos, sin poderse mover, ni sentir algún favor, ${ }^{127}$

o como hombre a punto de morir ahorcado: "si a uno le suspendiesen en el aire que no respirase", 128 o como quien, todavía consciente, pugnara por encontrar donde apoyarse: "colgado en el aire que no tiene en qué estribar". 129 Este símil, que aparece en Santa Ángela de Foligno, ${ }^{130}$ también lo repite Santa Teresa: "Es como uno que tiene la soga a la garganta y se está ahogando que procura tomar huelgo". 131 Juan de los Ángeles acude a la imagen del enfermo que sufre dolores tan terribles que "el miserable hombre no sabe adónde volver la cabeza ni espera más que la muerte o una cierta locura". ${ }^{132}$ La desesperación impotente sube de punto en el símil de San Juan de la Cruz: "El alma se siente . . a así como si tragada de una bestia en su vientre tenebroso se sintiese estar dirigiendo". ${ }^{133}$

Al desesperado dolor que limpia y pule, otros símiles agregan el dolor lleno de esperanza, recompensado al fin por gracias místicas más altas que las que se gozaron antes de la purgación pasiva. La comparación mejor y más usada, que encierra estos tres elementos de esperanza, dolor y recompensa, es la de la leña verde que empieza a arder y se convierte en un feo y negro tizón, del cual acaba por salir, sin embargo, pura y hermosa llama. Esta comparación se presta muy bien para el símbolo de la noche oscura, más oscura todavía antes del amanecer:

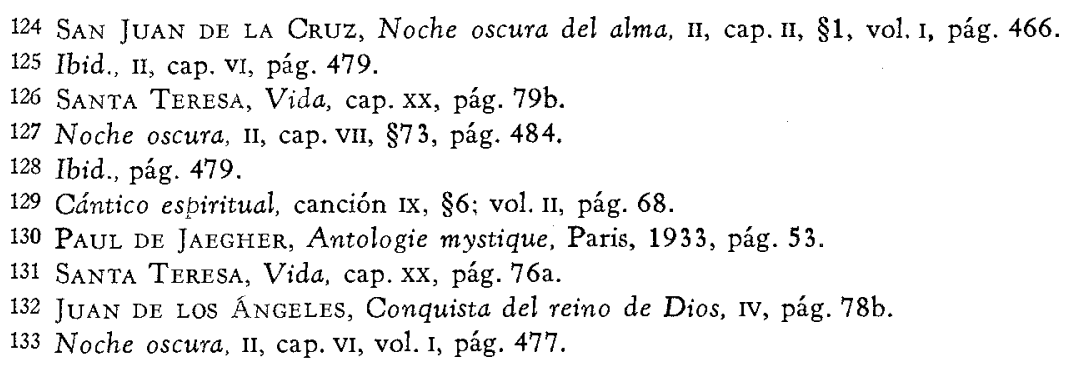


Esta purgativa y amorosa noticia ... se ha en el alma . . como el fuego en el madero para transformarlo en sí; porque el fuego material, en aplicándose a la madera, lo primero que hace es comenzarle a desecar, echándole la humedad fuera y haciéndole llorar el agua que en sí tiene... Luego le va poniendo negro, escuro y feo, y yéndole secando poco a poco, le va sacando a luz, y echando afuera todos los accidentes feos y escuros que tiene contrarios al fuego ... Y finalmente, comenzándole a inflamar por de fuera y calentarle, viene a transformarle en sí y ponerle tan hermoso como el mismo fuego. ${ }^{134}$

Este elemento de esperanza en el dolor, que sugiere los provechosos efectos del dolor mismo, aparece también en el símil de "la alquitara que por el fuego que recibe no cesa de gotear agua sudable y cálida", 135 o en la comparación del alma con el vaso que espera ser colmado, con el hombre ansioso de curación o de alimento, ${ }^{136}$ con el trompo que, inclinado, recibe el golpe del cordel y gira entonces a más y mejor, ${ }^{137}$ o con la fragua en que echan agua para avivar el fuego ("como suelen echar agua en la fragua para que se encienda y afervore más el fuego"). ${ }^{138}$

Por último, el acento acaba por desplazarse, del dolor mezclado con esperanza, a una vaga esperanza, expectación, imaginación, capricho, deseo de un no sé qué que, esperando lo mejor, no puede tampoco dejar de temer lo peor. Es como cuando al enfermo le disminuyen las fuerzas por la violencia de la fiebre: "Las fuerzas de los calenturientos con los crecimientos de la calentura se van apocando y la enfermedad se arraiga". 139 Es como la actitud de quien, teniendo hambre, no sabe qué alimento elegir, o como la de la mujer encinta a quien se le antojan las cosas más extrañas:

Ancontesce haber el hombre hambre y no determinarse qué manjar comerá mejor, y las mujeres preñadas muchas veces tienen deseos o antojos sin saber de qué. ${ }^{140}$

Es como niño absorbido en el juego del escondite (corregüela), ${ }^{141}$ o como dibujo que, a tener conciencia, esperara ansiosamente que le diesen color: "el alma está como la imagen de la primera mano y dibujo, clamando al que la dibujó para que la acabe de pintar", ${ }^{142}$ o como la piedra que, al caer, se va acercando a su centro. ${ }^{143}$

b) Francia: Si es verdad que Francia, hasta cierto punto, aprendió de los españoles la psicología de que hace gala su Siglo de Oro, a tal punto que

134 Ibid., II, cap. x, §1, vol. I, pág. 500 .

135 Abecedario, trat. $\mathrm{x}$, cap. IV, pág. 434b.

136 Cántico espiritual, canc. Ix, §6, vol. II, pág. 68.

137 Abecedario, trat. xIV, cap. II, pág. 473a.

138 Cántico espiritual, trat. XI, \$1, vol. II, pág. 74.

139 JUAN DE LOS ÁNGeles, Lucha espiritual, parte Ir, cap. III, pág. 322b.

140 Abecedario, trat. XI, cap. V, pág. $448 \mathrm{~b}$.

141 Lucha espiritual, parte II, cap. viII, vol. I, pág. $335 \mathrm{~b}$.

142 Cántico espiritual, canes. XI-XII, §1, vol. II, pág. 83 .

143 Ibid., pág. 83. 
sin Santa Teresa ni siquiera sería imaginable un Descartes, ${ }^{144}$ también es cierto que los franceses no fueron tan buenos discípulos en psicología del sufrimiento como en psicología del amor. Al describir la purgación pasiva, con sus dolores que pulen el alma, se limitan a señalar esos grandes e insufribles dolores, pero sin poner a la vista ninguna reacción del sujeto que sufre, como hacen en cambio los españoles con el hombre que, a punto de morir ahorcado, forcejea para respirar o trata de alcanzar el suelo. A los franceses parece interesarles otra cosa. Oponen siempre la purgación pasiva a la activa y así tratan de hallar dolores y sufrimientos más intensos para explicar esos sufrimientos pasivos. Si la purgación activa significaba arrancarle a un hombre sus ropas, la pasiva significa arrancarle la piel, desollarlo:

Ôter à un homme ses habits, c'est le traiter mal; mais ce n'est rien en comparaison de la rigueur qui l'écorcherait et qui ne laisserait aucune chair sur tous ses os. ${ }^{145}$

Es como verse forzado a comer el más repugnante trozo de carne podrida con todos sus gusanos ("une fourmilière de vers dans une pièce de boeuf pourri"). ${ }^{146}$ Es como una coyuntura dislocada, incesante tormento hasta que el hueso vuelve a su sitio. ${ }^{147} \mathrm{El}$ dominico Chardon exagera aún más la imagen de San Juan de la Cruz del prisionero desvalido en su mazmorra, añadiendo la idea de que el prisionero nada sabe de cómo es su encierro ("comment est disposé le lieu où il demeure"), ni si podrá nunca salir ("quelles sont les issues pour en pouvoir sortir"). ${ }^{148}$ Mme. de Chantal no se satisface con la comparación del desollado y añade que, después de lastimar la piel, la carne y los huesos, el dolor llega hasta la médula ("pénètre dans l'intime de la moelle"). ${ }^{149}$

Nada más natural que hacer pasar a los objetos inanimados los símiles originariamente referidos al hombre. Así las almas purificadas pasivamente son como olas que se rompen contra afiladas rocas, 150 como lienzo sometido a "une forte lessive" 151 (símil conocido por Osuna y San Juan de la Cruz), como carne que hacen picadillo ("hachée en menues pièces") ${ }^{152}$ y como pan que se ha tostado por completo ("un pain cuit où il n'y a plus rien à cuire"). ${ }^{153}$

144 Jacques Chevalier, $Y$ a-tril une philosophie espagnole?, en In memoriam Bonilla y San Martín. Madrid, 1927, vol. I, pág. 1 y sigs.

145 Fénelon, Oeuvres, xviI, 343, citado en Pourrat, Spiritualité, vol. Iv, pág. 301.

146 Marie de Vallées, en Dermenghem, la vie admirable et les révélations de Marie de Vallées. D'après des textes inédits, Paris, 1926, pág. 61.

147 Mme. Guyon, Autobiography, New York, 1880, pág. 73.

148 Pierre Chardon, O. P., La croix de Jésus, en Bremond, Histoire littéraire, vol. vili, pág. 65 .

149 Sainte Jeanne Françoise de Chantal, Oeuvres, vol. il, pág. 307, col. 2.

150 Mme. Guyon, Autobiography, pág. 289.

151 R. P. Bruno de Jésus-Marie, Madame Acarie, épouse et mystique, Paris, 1937, pág. 72 .

152 Alexandre Piny, Vie de la M. Madeleine, en Bremond, Histoire littéraire, vol. viII, pág. 127.

153 ID., La clef du pur amour, en BREMOND, Ibid., vol. viII, pág. 169. 
La interpretación española de la expectativa y el dolor esperanzado se clarifica en Francia a tal punto ${ }^{154}$ que Marie de Vallées recurre no sólo al símil de los antojos de la preñez, sino también a los dolores del parto. El jesuíta Crasset compara el alma que pasa por estas pruebas y sufrimientos con el paralítico del Evangelio que espera ansioso el movimiento de las aguas para poder entrar en ellas y ser curado; ${ }^{156}$ y Santa Margarita María Alacoque la compara con el lienzo en espera de que lo pinten ("comme une toile d'attente devant un peintre"). ${ }^{157}$

La diferencia entre la psicología española y la francesa consiste aquí, particularmente, en que los españoles rara vez subrayan el lado ontológico de ese sufrimiento (sólo lo hace Santa Teresa con su comparación del vaso aparentemente limpio en que el polvo salta a la vista tan pronto como el sol da en ella) mientras que los franceses ahondan en el problema de la "no correspondencia" entre la flaqueza humana y la abrumadora gracia divina, es decir, en el problema del alma que cobra conciencia de su fealdad fundamental a los rayos de las gracias místicas. Por esto el alma sabe que la delgada costra que escondía su tremedal de imperfecciones se resquebraja ahora, y un terrible mal olor se exhala fuera del charco:

Il en est à peu près comme d'un bourbier qui a pris au dessus une croûte; pendant que rien ne s'y remue, vous n'en sentez pas la mauvaise odeur, mais vous ne l'avez pas plutôt remuée qu'aussitôt une exhalaison s'en élève qui empeste l'air et ceux qui sont autour. ${ }^{158}$

El alma parece una gruta seca, pero súbita e inesperadamente el agua empieza a brotar en ella por donde menos se esperaba:

C'est comme une grotte qui paraît sèche de tous côtés et d'où l'eau réjaillit tout à coup par les endroits dont on se défiait le moins. ${ }^{159}$

El alma sufre como la cría del cuervo que, aunque teme el negro plumaje de sus padres, tiene que recibir de ellos el alimento ("les petits corbeaux, à qui les plumes noires de ceux dont ils tiennent la vie, feraient peur...., si peut-être ils n'étaient contraints de s'y accoutumer par le besoin d'en recevoir leur nourriture"), ${ }^{160}$ o como el aguilucho a quien el águila vieja coge entre sus garras ("au bout de l'ongle") y lo eleva hasta lo alto de una roca estéril ("coupeau d'un roc stérile") para acostumbrarlo al sol ("I'enlever vers le

154 Marie de l'Incarnation subraya particularmente su estado de attente, perte, etc. 155 Dermenghem, pág. 223.

156 P. Jean Crasset, Méthode d'oraison, en Bremond, Histoire littéraire, vol. vili, pág. 298.

157 Pourrat, vol. IV, pág. 403.

158 P. François Gilloré S. J., en Bremond, Introduction à la philosophie de la prière, pág. 258.

159 Fénelon, Instructions et Avis, en Albert Deplanque, La pensée de Férelon, Paris, 1930 , págs. 187 y sigs.

160 Père Joseph, en Louis Dedouvres, Le P. Joseph, pág. 67. 
soleil"), ${ }^{161}$ o como el enfermo a quien hay que aplicar emplastos molestos y abrasadores para curarlo mejor ("un epithème qui blesse et fait languir"), ${ }_{162}$ o como un niño a quien, por tener demasiada sangre, debe sangrarlo su padre, o como el niño que se porta mal en la calle, en compañía de otros niños, y a quien su padre debe castigar precisamente porque lo ama, y sin que haga el menor reproche a esos otros chicos:

Il nous arrive comme aux enfants qui n'ont pas encore l'usage de la raison qu'un bon père fait saigner dans leurs maladies; ils crient, ils pleurent, ne sachant pas que le peu de mal qu'ils endurent leur sert de remède; si le père en usait d'une autre sorte, il seroit cruel et dénaturé. Disons encore, si les enfants font des insolences publiques dans une place et que le père de l'un d'eux passe, il va à son enfant et le châtie et il laisse les autres ... Dieu châtie ceux qu'il aime advantage. ${ }^{163}$

El carácter de necesidad ontológica en todos los ejemplos precedentes resulta menos vívido que en el símil del polvo en el vaso, de Santa Teresa. Pero San Francisco de Sales habla acerca de un espejo que refleja las manchas de nuestra tez, más visibles en él mientras más fuerte se va haciendo la luz del día, que aviva el deseo de verse uno libre de ellas:

A mesure que le jour se fait, nous voyons plus clairement dans le miroir les taches et souillures de notre visage... ; et la même lumière qui nous fait voir ces tares et déchets, nous échauffe au désir de nous en nettoyer. ${ }^{164}$

Santa Juana Francisca de Chantal habla del agua cuyo fondo se hace trans. parente al influjo del sol. ${ }^{165}$

En este punto tienen cabida una serie de símiles de que carecen los místicos españoles y que confirman, por decirlo así, la necesidad ontológica de la pur gación pasiva por medio de una obediencia y un sentimiento racionales, fuente de la santa indiferencia y el amor puro, que desempeñan tan sobresaliente papel en el siglo Xvir francés. Aquí es de especial importancia la comparación del alma resignada con el arpista sordo, que no oye lo que toca, pero que por orden del señor ("pour contener un prince") continúa tocando, escúchesele o no, esté presente o ausente el príncipe ("le laissant là en sa chambre"). ${ }^{166}$ Otra com. paración es la del niño obediente que toma una medicina de mal sabor ("avec un incroyable goust"), porque ése es el deseo de su madre ("simplement et purement pour faire la volonté d'icelle"). ${ }^{167} \mathrm{El}$ estarse el alma sin consuelo se compara también con el valiente soldado que no necesita que lo empujen a la batalla con tambores y trompetas:

161 ID., Introduction à la vie spirituelle, en Bremond-Grolleau, ob. cit., pág. 68.

162 Santa Margarita María Alaconue, Oeuvres, vol. it, pág. 835.

163 Henr1 Mar1e Boudon, Dieu inconnu, Paris, 1757, pág. 62.

164 Introduction à la vie dévote, 1, cap. XXII, pág. 53.

165 Oeuvres complètes. Edition critique, Paris, 7 vols., 1877.1893, vol. II, pág. 522.

166 Amour de Dieu, libro 1x, cap. Ix, vol. II, pág. 137.

167 Ibid., pág. 144. 
Un vaillant soldat va de sens froid dans les périls . . ., mais le commun n'y va que lorsqu'il est poussé. On est contraint pour l'y faire aller d'user du bruit, des tambours et des trompettes. ${ }^{168}$

También conocen los franceses, finalmente, la visión retrospectiva de la "noche" como "feliz" porque el fin de esta negra noche en la clara mañana de la unión mística quita a las tinieblas su negrura, como, entre los españoles, sólo veíamos en San Juan de la Cruz. Su ejemplo de la "escalera disfrazada" 169 reaparece en Francia de modo particular, lleno de espíritu preciosista y morosamente desarrollado. En un diálogo de Desmarets de Saint Sorlin, lleno de optimismo, Eusebio explica a Filedón que, si un hombre desciende a la prisión de la Nada, asciende luego por maravilloso artificio a la más alta cúpula:

Eusìbe: Ces escaliers son faits d'une invention admirable; car plus on descend bas, plus on s'élève . . On se trouve élevé par une machine incompréhensible jusçu'au dôme de l'Espérance . . A A proportion que l'on a à descendre, à proportion on se sent élevé tout à coup par cette machine invisible.

PHILÉdon: Voilà une belle invention et cet architecte était admirable.

Eusèbe: Ce grand Architecte c'est Jésus-Christ lui-même. ${ }^{170}$

De manera igualmente retozona, Marie de Vallées habla del niño que cayó dentro de un charco y que, sacado de allí, recibió una paliza de su madre ("elle lui bailla le fouet bien fort"), pero recibió también sus ropas recién lavadas y limpísimas ("lui lava sa robe et la lui rendit blanche comme auparavant"). ${ }^{171}$ La estatua se somete gustosa al cincel y el martillo del escultor con la esperanza de "être placé dans l'église sur les autels et y recevoir des encens". ${ }^{172}$ Esta animación de las cosas para explicar los fenómenos místicos podemos encontrarla todavía hoy en el francés Henri Bergson, cuando compara el alma del místico con la máquina que constantemente renueva todas sus partes a costa de grandes dolores para convertirse en más eficaz instrumento. ${ }^{173} \mathrm{Al}$ lado de esta creación original encontramos, desde luego, las reiteradas fórmulas españolas de que el alma es la piedra que el escultor debe trabajar con finos instrumentos ("marteau, ciscau, d'autres outils plus délicats") ${ }^{174}$ para lograr "la parfaite image"..175

Una última particularidad francesa es el rapport fatal teológico entre el comparandum y el comparatum. Si todo el proceso místico es una asimilación

168 Pierre Camus, L'esprit de Saint François de Sales, Paris, 1747, cap. XxiI, pág. 425.

169 Noche oscura del alma, II, cap. xvin, \$2, vol. I, pág. 538.

170 Jean Desmarets de Saint Sorlin, Les délices de l'Esprit, jornada xir, en Bremond, Histoire littéraire, vol. vi, pág. 508.

171 Marie de Vallées, en Dermenghem, pág. 189.

172 De Barnik̀res-Louvigny, Le Chrestien intérieur, vol. Ii, pág. 248.

173 Les deux sources de la religion et de la morale, Paris, 1932, pág. 247.

174 San Vicente de Paul, en J. Calvet, St. Vincent de Paul. Textes choisis ct comentés, Paris, s.a., pág. 308.

175 Fríre Laurent de La Résurrection, Maximes spirituelles pour acquérir la présence de Dieu, Paris, 1692, pág. 138, en Pourrat, vol. Iv, pág. 166. 
de Cristo, entonces la noche oscura de la purgación significa caminar con Cristo sobre las aguas ("marcher sur les eaux") sin apoyo alguno, sin contar aún con la mano de Cristo como guía y sin ser capaz de "demander à la nature le chemin en un pays où [I'on] n'a jamais été". 176 Otro rapport fatal, más profundo, afirma que el alma sometida a prueba es un miembro del Cuerpo Místico y que debe adecuarse a la Cabeza coronada de espinas ("Il serait un désordre ... si les membres nourris de délicatesse étaient liés à un chef percés d'épines")..$^{177}$

\section{V}

\section{UNIO MYSTICA}

a) España: Entre los símiles españoles para la unión mística del alma con Dios, más allá de las visiones e iluminaciones, hay algunos que se refieren al primer y súbito conocimiento, o al goce anticipado, y otros a la tranquila beatitud, a la divina penetración, absorción y sumersión del alma. Se advierte un esfuerzo extremo por señalar mediante comparaciones el avance del alma, dentro de la vida mística, hacia grados más altos todavía.

Los místicos españoles quieren explicar por comparaciones lo que sienten en los momentos iniciales del repentino y beatífico arranque de amor. Santa Teresa imagina "una cometa que pasa de presto" o "un silbo penetrativo" o "un trueno aunque no se oye ruido". ${ }^{178}$ Diego de Estella habla de "golpes de eslabón para sacar del pedernal . . centellas de fuego". ${ }^{179}$ Fray Luis de León habla del "relámpago que luce y pasa en breve". ${ }^{180}$ San Juan de la Cruz se siente de pronto invadido por un atronador torrente de agua:

De tal manera se ve el alma embestir ... que le parece que vienen sobre ella todos los ríos del mundo . . . , no sólo le parece sonidos de ríos, pero aún poderosísimos truenos. ${ }^{181}$

El alma llega súbitamente a Dios "como la garza cuando lanza el halcón que la prende"; ${ }^{182}$ en su arrebato de éxtasis es como

alguna vasija que contiene agua o otro licor, el cual poniendo fuego se calienta; empero cuando hierve e bulle parece . . . no caber en sí, mas ex. ceder a sí mesmo el licor que antes estava seguro e ser llevado sobre sí. ${ }^{183}$

176 Crasset, Lettre de direction, en Bremond, Histoire littéraire, vol. viII, pág. 295.

177 Chardon, La Croix de Jésus, en Bremond, Ibid., vol. viII, pág. 39.

I78 Moradas, lib. vi, cap. II, pág. 372 b.

179 Meditaciones devotísimas del amor de Dios, ed. Ricardo León, Madrid, 1920, $\$ 76$.

180 Fray Luis de León, Los nombres de Cristo, ed. Federico de Onís, Madrid, 1914-1917, 3 vols., vol. III, pág. 83.

181 Cántico espiritual, canc. xIv, \$9, vol. 11, pág. 105.

182 Abecedario, trat. XII, cap. 11, pág. 454a.

183 Ibid., trat. vi, cap. II, pág. 379 b. 
La misma efusión extática del alma en Dios la compara Diego de Estella con el agua que hasta en prisión dorada busca por donde escapar:

No hay redoma de oro en que el agua esté contenta, y así, en hallando por donde salir, luego deja el lugar ajeno y se va al suyo. ${ }^{184}$

La unión extática no permanente se concibe también como un goce anticipado de la llamada unión transformante y se compara por esto con la fruta que sólo pudiéramos oler y no paladear ("como melón que se le metiera en la boca sin le dar a sentir sino solamente el gusto") ${ }^{185}$ o con una piedra preciosa oculta en relicario de oro, cuyas virtudes sentimos, pero que permanece en su encierro, ${ }^{186}$ o con la feliz presencia de una persona querida en una pieza a oscuras, presencia de la cual estamos seguros aunque no se nos ofrezca a la vista. ${ }^{187}$

La plenitud de la unión mística transformante se expresa ante todo por símiles de penetración. Los españoles recogen el antiguo y famoso símil de la penetración del alma por Dios comparada con la penetración del hierro por el fuego, imagen que encontramos en San Bernardo de Claraval, Ricardo de Saint-Victor, Ruysbroeck, Santa Ángela de Foligno y otros. Pero los españoles, ante la vigilante Inquisición - "los mastines del rebaño católico", como la llamó Cervantes en su Persiles-, llegan casi a destruir el símil, aunque añaden al mismo tiempo que el hierro continúa siendo hierro y que no se transforma en fuego, con lo cual se ponen a salvo de una posible acusación de panteísmo. Dice Fray Luis de León:

El hierro que se enciende del fuego, aunque en el ser es hierro y no es fuego, en el parecer es fuego y no hierro. ${ }^{188}$

Y Juan de los Ángeles cambia el viejo símil de este modo:

El hierro caldeado se queda hierro aunque vestido de las calidades del fuego, pareciendo más fuego que hierro por esencia, aunque verdaderamente no lo es sino por participación. ${ }^{189}$

El carácter penetrativo de la unión mística también se expresaba tradicionalmente como la imagen del aire o la nube radiantes, traspasadas por el sol ("Quomodo solis luce perfusus aer"). Esta comparación llega desde San Bernardo, pasando por Giordano de Pisa (1305) y Meister Eckart, hasta Fray Luis de León. ${ }^{190}$ Juan de los Ángeles sugiere el símil del rayo de sol que parece una parte del sol mismo: "Permanecer suspenso en Dios como el rayo en el

184 Meditaciones devotísimas, pág. 343.

185 Abecedario, trat. v, cap. Iv, pág. 374a.

186 Moradas, lib. vI, cap. IX, pág. 398b.

187 Ibid., lib. vil, cap. I, pág. 410a.

188 Los nombres de Cristo, vol. Ill, pág. 189

189 Conquista del reino de Dios, pág. $47 \mathrm{a}$.

190 Los nombres de Cristo, vol. in, pág. 217 
sol". ${ }^{191}$ También aquí San Juan de la Cruz es el más profundo, cuando, ante el difundido símil medieval que compara la virginal concepción de María con el cristal de colores atravesado por la luz, lo explica con el alma que efectiva. mente concibe a Dios, "estando ambos en uno, como . . . la vidriera con el rayo del sol". ${ }^{192}$

El tercer símil de penetración, y el que mejor acierta con el carácter trans formante final y con la sorpresa inicial de la chispa que se enciende, es el del madero que gradualmente se va convirtiendo en fuego, a medida que la llama lo penetra y devora:

El madero no bien seco . . calentado, comienza primero a despedir humo de sí y a dar de cuando en cuando algún estallido ... y dende a poco se torna a encender otra vez y a apagarse también, y así hace la tercera y la cuarta, hasta que al fin el fuego, ya lançado en lo íntimo del madero y hecho señor de todo él, sale todo junto y por todas partes afuera sus llamas, las cuales, prestas y poderosas y a la redonda bullientes, hacen parecer un fuego el madero. ${ }^{193}$

San Juan de la Cruz hace de este símil tradicional un gigantesco símbolo, con el cual se explica que el fuego purgativo del alma y el fuego transformante es el mismo Amor Divino, que sólo aparece al alma bajo forma diferente según la mayor o menor altura que ella haya alcanzado en su mística ascensión:

El mismo fuego que transforma en sí el madero incorporándose en él, es el que primero le estuvo disponiendo para el mismo efecto. ${ }^{194}$

Otro símil para la interpenetración es el de las dos velas, tal como lo encontramos en Santa Teresa:

. . como si dos velas de cera se juntasen en extremo que toda la luz fuese una, y que el pabilo y la luz y la cera es todo uno. ${ }^{195}$

San Juan de la Cruz dice casi lo mismo de las estrellas y el sol:

La luz de una estrella se junta y une con la del sol que ya el que luce no es la estrella sino el sol, teniendo en sí difundidas las otras luces. ${ }^{196}$

\section{Y Santa Teresa:}

Como si en una pieza estuviesen dos ventanas por donde entrase gran luz; aunque entre dividida, se hace todo una luz. ${ }^{197}$

191 Vida perfecta, diálogo IV, pág. 218a.

192 Cántico espiritual, canc. xxvi, vol. II, pág. 187.

193 Nombres de Cristo, vol. II, pág. 235. Compárese también vol. I, pág. 239.

194 Noche oscura, II, cap. x, \$3, vol. II, pág. 501.

195 Moradas, lib. vil, cap. vil, pág. $412 \mathrm{a}$.

196 Cántico espiritual, canc. XXIl, §3, vol. II, pág. 161.

197 Moradas, lib. vil, cap. vIl, pág. $412 \mathrm{a}$. 
El concepto de la sumersión del alma en Dios se mantiene en los símiles del buzo ("como quien se zabulle en el agua"), ${ }^{198}$ de la "esponja que ha dado consigo en la fuente" 199 y se queda henchida de agua, o de la lluvia que se pierde en el mar. ${ }^{200}$ Esos símbolos de una muerte bienaventurada para la unión mística no satisfacen a un San Juan de la Cruz, que intenta de algún modo representar el crecimiento de la vida de Dios en el alma. Y así habla del "aire que cuanto más limpio está de vapores más le clarifica y calienta el sol", ${ }^{201}$ o de las chispas que produce "un encendido horno o fragua cuando lo hornaguean o trabucan el fuego y afervoran la llama", ${ }^{202}$ o de las centellas dentro de la gran llama del madero:

Aunque habiendo entrado el fuego en el madero le tenga transformado en sí y esté ya unido con él, todavía afervorándose más el fuego y dando más tiempo en él, se pone mucho más candente e inflamado hasta centellear fuego de sí y llamear. ${ }^{203}$

b) Francia: Los ejemplos franceses para el arrobamiento extático no proceden tanto de la esfera psicológica del conocimiento y la sorpresa, como del juego de las analogías racionales, gratas al humanismo, o bien de la natura. leza. Ante la unión extática que ocurre después de las pruebas y que conduce una vez más a ellas, Surin piensa en un pigmeo que se ha agrandado hasta alcanzar la altura del gigante Tifeo; ${ }^{204}$ Camus en la pequeña alondra que se remonta ebria de luz y después de un momento vuelve a bajar al suelo -la limitación de la unión crucificante:

Les petites alouettes sont amoureuses de la lumière, ce qui fait que quand le temps est clair qu'elles s'eslèvent autant qu'elles peuvent vers le soleil, en chantant leur ramage. . . mais enfin quand elles n'en peuvent plus, elles cessent tout à coup de voler et de chanter et s'abbattent en terre. ${ }^{205}$

San Francisco de Sales imagina que el ruiseñor, silencioso ("le rossignol quand il fait ses pauses"), es arrebatado por una íntima melodía de Amor, como la que lo arrebata cuando canta. ${ }^{206}$

En San Francisco de Sales, el concepto español de la experiencia anímica directa de una presencia beatífica se transforma en la imagen de los esposos sentados plácidamente uno junto a otro y enamorados y contentos sin necesidad de hablarse:

198 Abecedario, trat. XX1, cap. VII, pág. 572a; y JUAN DE LOS Ángelis, Conquista pág. $145 \mathrm{a}$

199 Osuna, Ley de amor, en EtChegoyen, L'amour divin, pág. 227, nota 1.

200 Moradas, lib. vir, cap. vir, pág. $412 \mathrm{a}$.

201 Llana de amor viva, III, $\$ 34$, vol. II, pág. 364

202 Ibid., 11, $\$ 9$, pág. 320.

203 Ibid., prólogo, §3, vol.1I, pág. 284.

204 Surin, Cantiques spirituels de l'Amour divin, Paris, 1664, Cantique xxxix, pág. 143.

205 Théologie mystique, pág. 369.

206 Amour de Dieu, lib. xil, cap. v, vol. II, pág. 328. 
Les époux humains se contentent parfois d'être auprès ou à la vue de l'épouse sans lui parler et satisfaits de savourer cette bien aimée présence, non par aucune considération qu' ils fassent sur elle, mais par une certaine tranquillité que leur esprit prend en elle..$^{207}$

La Madre Angélique Arnauld, de Port Royal, describe la felicidad del alma en unión comparándola con la felicidad de Santa Magdalena sentada a los pies del Señor ("Sainte Madeleine aux pieds de Jésus Christ qui écoute en paix"). ${ }^{208}$

Las comparaciones místicas francesas tienen otro matiz, que las diferencia de las españolas: el desesperado afán del alma por una unión que parece imposible. El agudo análisis de este anhelo de éxtasis abarca tanto el deseo de ser absorbido por Dios como el de absorber a Dios. San Francisco de Sales ejemplifica este deseo mediante el símil de un niño que quisiera casi devorar el pecho de la madre o penetrar en él:

On voit un petit enfant affamé si fort collé au flanc de sa mère et attaché à son tétin, presser avidement cette douce fontaine de suave et désirée liqueur, de sorte qu'il est advis, qu'il veuille ou se fourrer tout dans ce sein maternel, ou bien tirer et sucer toute cette poitrine dans la sienne. ${ }^{209}$

Surin, con su acostumbrado lenguaje emotivo, habla análogamente del niño que no se satisface con estar echado en el regazo materno ("d'estre au giron de sa mère"), sino que quiere volver a su seno ("r'entrer dedans ses flancs , ... se cacher jusqu'au profond de ses entraillles"). ${ }^{210}$

Los símiles de penetración son muy parecidos a los españoles. Encontramos el momento inicial del éxtasis combinado con el de la unión plena en el símil de Camus de la chispa que prende fuego en un haz de paja y que, al soplar el viento, extiende la llama a un montón de leña, hasta que todo arde:

La flamme légère allummée dans la paille allume un gros tas de bois, qui fait une grande ardeur et ceste ardeur augmentée par le vent pousse de grandes flammes. ${ }^{211}$

Entre los símiles sencillos de penetración reaparece en Bérulle el del sol que traspasa la vidriera, de San Juan de la Cruz:

Le soleil imprime sa clarté, sa splendeur et son espèce vive et éclatante dans le cristal poli. ${ }^{212}$

207 Ibid. lib. vi, cap. vin, vol. I, pág. 331.

208 Entretiens et Conférences de la R. M. Angélique de Arnauld, Bruxelles, 1757, pág. 251, en Bremond-Grolleau, Anthologie, pág. 180.

209 Amour de Dieu, lib. III, cap. x, vol. I, pág. 200.

210 Cantiques spirituels, pág. 62.

211 Théologie mystique, pág. 388

212 Mystére de Jésus, pág. 579, en Claude Taveau, Le cardinal de Bérulle, maître de vie spirituelle, Paris, 1933 , pág. 174. 
La imagen de las estrellas traspasadas por la luz del sol, de San Juan, aparece así elaborada en San Francisco de Sales:

Les estoiles sans perdre leur lumière ne luisent plus en la présence du soleil, ains le soleil luit en elles et sont cachées en la lumière du soleil. ${ }^{213}$

Pero lo que interesa a los franceses no es la penetración ni la inmersión en la unión mística, sino una cosa intermedia, una absorción, o quasi-absorción, que a veces ponen a salvo del panté́smo y el quietismo, dando al elemento absorbido una conciencia alegórica que atestigua la bienaventuranza experimentada en la absorción. Subrayan este punto mucho más que los místicos españoles. La gota de agua sorbida por el mar, de Santa Teresa, aparece como una indestructible personalidad en San Francisco de Sales:

Si une goutte d'eau élémentaire jetée dans un océan d'eau naphe, estoit vivante, ne crieroit-elle pas de grand joie: Je vis voirement, ains cet océan vit en moi et ma vie est cachée en cet abisme. ${ }^{214}$

Y una vez más, la claridad francesa quita todas las posibles tachas de panteísmo en aquellas palabras del P. Chardon en que nos muestra que la gota de agua en el mar pierde el temor de disolverse en él:

La créature ne délaissant point d'être créature, elle y perd pourtant son non-être, et, comme une goutte d'eau se confondant avec la mer où elle est engloutie, elle perd la crainte de devenir moindre. ${ }^{215}$

Esto nos sugiere hasta cierto punto cómo han de comprenderse los otros símiles de absorción y penetración; por ejemplo la esponja de Surin, que es (vale decir, se siente) traspasada por una preciosa esencia ("une éponge pénétrée par une liqueur donnant une allégresse et suavité inexplicable"). ${ }^{216}$ En San Francisco de Sales hallamos una comparación semejante: la del perfume que penetra en el algodón y es absorbido por él, aunque lo que aquí se subraya es la intensidad de la unión, y se utiliza la imagen exactamente como los españoles utilizaban la del hierro ardiente:

L'onguent précieux ou le baume qui tombent sur le coton se mesle et s'unit tellement de plus en plus, petit à petit, avec iceluy qu'en fin on ne sçaurait pas dire si le coton est parfumé ou s'il est parfum, ni si le parfum est coton ou le coton parfum. ${ }^{217}$

Esta idea de San Francisco de Sales lleva implicado aquel otro símil español

213 Amour de Dieu, lib. vi, cap. XII, vol. I, pág. 347.

214 Ibid., lib. vi, cap. XII, vol. I, pág. 346.

215 Chardon, La croix de Jésus, pág. 450, en Bremond, Histoire littéraire, vol. vIII, pág. 46.

216 Surin, Lettres spirituelles, ed. Louis Michel et Ferdinand Cavallera, Toulouse, 1928, vol. II, pág. 141.

217 Amour de Dieu, lib. vir, cap. I, vol. II, pág. 10. 
del líquido que quiere salir de la botella, atraído por el lugar que le corresponde. Por eso dice también, a propósito del alma que se derrama en Dios:

C'est pourquoi, comme un baume fondu qui n'a plus de fermeté ni de solidité, elle se laisse aller et écouler en ce qu'elle aime. ${ }^{218}$

Jean de Saint-Samson se siente perdido y disuelto en un inmenso fuego devorador ("se sentant et se voyant perdu et fondu dans l'immensité de ce feu tout dévorant"). ${ }^{219}$ Esta felicidad de perderse está también en el "átomo perdido y consumido en un horno" de Santa Margarita María Alacoque ("un petit atome qui se consumait dans cette ardente fournaise"), ${ }^{220}$ o en su "pez perdido en el vasto océano" ("comme un petit poisson dans le vaste océan de la mer"), ${ }^{221}$ así como en el símil de François de Clugny, del "gigante que abraza un átomo que se pierde en sus manos y ya nunca se vuelve a encontrar". ${ }^{222}$

Chardon intenta inclusive aclarar cómo el alma, una vez unida a Dios, toma parte en la vida divina, y la compara con la esponja que se ha llenado de agua de mar y es agitada luego en todas direcciones en medio de este mar infinito:

ainsi qu'une éponge pleine et remplie d'eau en toute sa capacité, flottant dans le sein d'une mer, dont toutes les dimensions de hauteur, de profondeur, de largeur et de longeur sont infinies. ${ }^{223}$

Esta vida mística después del matrimonio místico no aparece con mucha riqueza de fantasía en los franceses, si los comparamos con los españoles. Los franceses la presentan "científicamente", como un proceso de sístole y diástole, para el cual aplican los términos de respirer y aspirer.

De même qu'en respirant nous attirons l'air frais de dehors en notre poitrine et en aspirant nous repoussons le chaud, ainsi en respirant par le recueillement nous attirons Dieu en nous, et en aspirant nous nous jetons entre les bras de sa bonté. 224

El jesuíta Saint-Jure desarrolla en todos sus pormenores el mismo símil de la vida mística:

La respiration se fait lorsque le poumon vient par son mouvement de diastole et d'élargissement à attirer l'air frais qu'il communique après par i'artère veineuse au coeur, et que le coeur aussi par un mouvement sem-

218 Ibid., lib. vi, cap. XII, vol. I, pág. 345.

219 Jérôme de la Mère de Dieu, La doctrine du vénérable Frère J. de Saint-Sam. son, Paris, 1925, pág. 69.

220 Pourrat, pág. 406.

221 Santa Margarita María Alacoque, Oeuvres, vol. II, pág. 510.

222 Françors de Clugny, De l'oraison du pécheur, xv, en Bremond, Histoire littéraire, vol. viI, pág. 308.

223 Chardon, La croix de Jésus, pág. 450, en Bremond, Histoire littéraire, vol. viII, pág. 46.

224 Camus, L'Esprit de Saint François de Sales, Paris, 1747, pág. 418. 
blable attire à soi, et, après s'en être rafraîchi, le renvoie, d'où il est venu, par le mouvement de systole et de rétrécissement... De même l'air spirituel nous est nécessaire. C'est pourquoi nous devons incessamment aspirer Jésus Christ et l'attirer en nous, et après, comme il nous vient du sein de son Père, nous devons le lui renvoyer et le lui rendre. ${ }^{225}$

Surin interpreta la vida mística como si precisamente fuera la beatitud de un francés patriota y de gustos artísticos cultivados a quien van mostrando el Palacio del Louvre, donde se exhiben los más bellos muebles:

En peu de temps II [Dieu] lui decouvre

Les plus beaux meubles de son Louvre. ${ }^{226}$

Saint Jure toma de San Juan de la Cruz la imagen de la llama viva que abrasa el alma sin dolor, sumiéndola en gloriosa muerte, con el símil del leproso, que ve lleno de júbilo la creciente destrucción de su cuerpo, único muro que lo separa de Dios, hasta que finalmente queda con el alma libre por entero para la más alta unión. Saint Jure hace exclamar al leproso:

Entre Dieu et moi il n'y a point autre milieu que cette muraille de boue, qui est mon corps ... A mesure qu'elle se ruine et tombe par pièces, je chante et je me réjouis pour me voir plus près de cette veue désirée et de mon bonheur. ${ }^{227}$

\section{RESUMEN Y CONCLUSION}

De los símiles estudiados se desprenden algunas claras conclusiones. La energía pragmática del español presenta la relación entre meditación activa (ejercicios espirituales) y contemplación pasiva como de causa a efecto (pedernal y chispa, llamar y abrir, viajar y descansar, navegar y desembarcar, cocinar y comer, aprender un oficio y dominarlo); el francés, analítico y teórico, no reconoce esta relación de causa a efecto, y consiguientemente rechaza todo símil de este tipo. El concepto de meditación como imperfección y el de contemplación como perfección lo comparten ambos países. Pero España revela en los respectivos símiles sus peculiaridades de tierra árida (arroyo y fuente, arcaduces y fuente), de agricultura arcaica (el lento o rápido arar de los bueyes), de país de viejos castillos (muros exteriores y torre interior), de sociedad feudal (escudero y caballero), de valoración barroca del arte (tallar y pintar, mirar y crear el Escorial, vihuela destemplada y templada, vaso de barro y de oro). Francia mira los objetos y hechos de tal modo que aparecen menos franceses que humanos en general, pero presentándolos con la más grande precisión (vista detallada y vista total de una corona, olor de flores

225 Jean Baptiste Saint-Jure, S. J., L'union avec N. S. Jésus Christ dans ses principaux mystères, en BREMOND, Introduction à la philosophie de la prière, pág. 329.

226 Cantiques spirituels, pág. 63.

227 Saint-Jure, De la connaissance et de lamour du fils de Dieu Nostre Seigneur Jésus Christ, Paris, 1933, pág. 897a. 
separadas y perfume compuesto, luz de candil y de sol, contemplación de una pintura por un profano y por un artista, servir en cocina y servir en gabinete), o con esprit (el león pintado y el vivo, lo que ve el astrónomo y lo que ve el hombre que por primera vez mira el sol, hablar por gramática y por práctica). Una tercera relación en que insisten unos y otros es la de la difícil actividad frente a la fácil pasividad. Una vez más, España, aunque alude a actividades humanas en general, nos hace ver pintorescos detalles de la Península, con estrictas oposiciones (remar y navegar con vela, el labrar la tierra y el crecer por sí sola la simiente, el carro pesado y el ligero, traer agua por los arcaduces y obtenerla de la lluvia, pelar la fruta y gustarla, el niño que camina y el llevado en brazos, el niño ansioso de alimento y el amamantado, el gusano de seda que hila su capullo y el capullo que se transforma en mariposa). Los franceses, con su afán de claridad, dan más detalles en sus símiles y, en su nonchalance, conciben la pasividad como un laisser faire. Así disminuyen el contraste entre actividad y pasividad, aun allí donde sus imágenes coinciden con las de los españoles (galeras a remo y galeras empujadas por el viento, el masticar y el beber, la leche tomada de la cuchara y del pecho, la abeja en la flor y en la colmena, el centinela que se pasea y el que se queda en un mismo sitio). En general, los símiles españoles de meditación y contemplación, a pesar de la energía y el rigor españoles, aparecen como en una conversación familiar; los franceses, a pesar de su típica nonchalance, se nos presentan en elaborado estilo "homérico". Persuasión práctica frente a demostración teórica; gusto popular frente a estética académica.

El tema de la purgación activa del alma inspira al ascetismo español imágenes de poético colorido (el cielo nublado que la lluvia aclara) y de gran movimiento e intensidad (el mantel manchado que se lava con lejía caliente, el pájaro cazado con liga y luego desasido y liberado, la serpiente que se estruja entre filosas rocas para mudar de piel); el mismo tema lleva a los franceses, con su mesurado laisser faire, a entregarse simplemente al renunciamiento y la abstención (pisar sobre polvo y lodo, renunciar a ser propietario), para presentar de manera gradual y orgánica ese desasimiento (la serpiente que muda su piel con lentitud; quitarse las ropas, una después de otra; andar de puntillas; el pichoncillo implume, aunque protegido por su madre). El papel de Dios en esta purgación, cuando se cambia en recogimiento, es para el espiritualismo español una curación en que Dios, como médico, debe ayudar (el niño travieso a quien hacen darse de cabezadas contra una piedra, el pájaro acostumbrado a la jaula, el gavilán con los ojos vendados, la mariposa que se quema las alas, etc.). Los franceses reservan la intervención de Dios a una etapa posterior, e insisten aquí racionalmente en la necesidad de la purgación, mediante consideraciones filosóficas y humanísticas (el verdadero filósofo domina los instintos animales; los antiguos se protegían con coronas de flores, para preservarse contra los ruidos molestos). En general, las exageraciones barrocas en los ascéticos españoles son más eficaces en este particular dominio de la actividad que las suaves fórmulas del clasicismo francés, que diluyen un tanto el desasimiento haciéndolo "natural".

Los españoles analizan la etapa mística de la contemplación infusa bajo 
todos sus aspectos empíricos y psicológicos. Con su tradicional don introspectivo, heredado de los árabes, hacen observaciones sobre la acción de Dios en las almas y sobre el estado de quietud y de éxtasis (la paja atraida por el ámbar, la gota de vinagre que cava la tierra, el cazador que hiere a la presa). Los españoles, tan aficionados a pormenores psicológicos, llegan hasta intentar gráficas descripciones del aquietamiento de la voluntad (los asnos que dan vueltas a la noria con los ojos vendados), del entendimiento (ponerse sin vacilaciones en los cuernos del toro), de la memoria (la cera en que se imprime el sello). Por esto presentan el alma contemplativa en un proceso de creciente pasividad (el desnudo es vestido; el niño recibe los besos, la leche y las caricias de su madre; las manos temblorosas se aquietan). El espíritu intelectualista de Francia, a quien evidentemente repugna la introspección religioso-psicológica, lo mismo que el devenir en cuanto opuesto al ser, está convencido de su incapacidad de analizar el fenómeno sobrenatural en el alma, como tan a menudo señalan sus escritores. En la contemplación pasiva atienden a su propio asentimiento y laisser faire, es decir, a cierta cooperación y actividad propias. De ahí que recurran a símiles que traducen una quietud sólo aparente (las lentas aguas del río, los planetas que giran alrededor del polo, el hierro que se mueve hacia el imán, el niño que patalea y se esfuerza en acercarse al pecho materno, el niño que se queda quieto cuando su madre lo viste).

El estado inceptivo de quietud, el tremendo suceso que transcurre más allá del abismo que separa a los místicos de los otros mortales, atrae, como es natural, el común interés de franceses y españoles. Éstos toman espontáneamente sus similes, para expresar el súbito arrobamiento de la quietud, de su experiencia vital (el "ojo que cayendo se va sabrosamente al sueño ciego", el que vela toda la noche y después lo sorprende la aurora, el agua viva que corre bajo el hielo muerto, el polluelo ya vivo aunque permanezca todavía en el huevo, una refrescante unción que nos echasen en la médula, el olor a incienso que viene súbitamente de un lugar oculto, el pensamiento que llega al corazón y nos maravilla). Los símiles franceses parecen construidos de modo menos espontáneo y más racional, porque recurren a situaciones más concretas $e$ individuales, tomadas no sólo de la vida misma, sino también de la Biblia y de la Antigüedad, a fin de construir las analogías más precisas para significar el estado místico inceptivo (oír tenuemente la voz del amigo mientras dormitamos, el desviarse un río por la rotura del dique, los invitados a las bodas de Caná que de pronto saborean el vino cuando esperaban agua, la inspiración que se infunde en el alma del poeta griego, la sorpresa de la criada al oír golpes en el sótano, el ciego sorprendido cuando alguien lo toca).

No siendo tradicionalmente filósofos, los españoles parecen interesarse menos en la significación metafísica del estado de quietud que en la purgación previa. Consiguientemente sus símiles son aquí algo vagos y vulgares (la casa vacía, la burra en que va montado el Señor, el alba que ya es día, el enfermo obligado a guardar cama, los ruidos del molino que cesan definitivamente, la nave que penetra en alta mar). Los franceses ven de modo más filosófico, y como moralistas, este estado final de quietud y describen el fenómeno usando en parte símiles humanísticos y sociales típicos de Francia (el papel en blanco 
en que alguien está escribiendo, el prisionero a quien ponen en libertad, el hombre libre a quien atan para bien suyo, la pobreza de Sócrates y Diógenes, la propiedad vendida, la venda sobre los ojos, el líquido que se mantiene quieto, el perfecto mecanismo de un reloj). Como moralistas, los franceses subrayan que el alma nunca está lo bastante limpia para las gracias que se le conceden (el animal hediondo que lleva una carga perfumada, el vino bueno echado a perder por los restos del malo).

En cuanto a las purgaciones místicas pasivas, el primer aspecto traducido en imágenes por los españoles en trance de descubrir experimentalmente verdades espirituales es el de la acción divina que limpia y pule el alma, y que el alma necesita (el tornero que usa sus instrumentos más afilados; el jabón y la lejía; el fuego que quita el orín; el sol que pone en evidencia el polvo del vaso). El francés, sintetizador, dando esto por consabido, no insiste en ello en esa forma individualísima a que los españoles se ven directamente llevados por su experiencia, sino que lo vierte en amplios símiles que hemos llamado "retrospectivos". Así, el racionalismo francés anima hasta los objetos inanimados en vista de la significación "sentida" y retrospectivamente "comprendida" de sus "sufrimientos" (la estatua que se somete a la dolorosa acción del cincel, pensando en el sitio que le espera en el altar, o en la suprema perfección artística; el niño que cae en el charco y a quien castigan, pero a quien dan también ropa limpia; las manchas en nuestro rostro, que, reveladas por la luz, nos estimulan a quitárnoslas). El segundo aspecto es el del dolor desgarrador de una víctima indefensa. La atmósfera de los autos de fe y la sombría imaginación de un Valdés Leal o un Quevedo corresponden a este grupo de símiles españoles (el prisionero en oscura mazmorra, el malhechor en galeras, el enfermo que enloquece, el hombre devorado por la fiera). Los símiles que aparecen en Francia son más siniestros aún, pero tienen el evidente propósito de traducir la experiencia de los persistentes dolores "pasivos", más intensos que los de la purgación activa (el desollado y el quemado, el que tiene que comer carne podrida y agusanada, la coyuntura dislocada que vuelven a enderezar, el prisionero inocente que despierta en hórrida celda). Asimismo los franceses extienden el dolor a objetos inanimados (las olas que se rompen en las rocas afiladas, el lienzo sometido a un áspero lavado, la carne que hacen picadillo, el pan que se tuesta por completo). El tercer aspecto en España es el de la esperanza que acompaña al dolor y lo hace tolerable (el madero oscuro que se transforma en llama, la alquitara que produce líquido por el calor, el enfermo que se cura, el trompo tambaleante a quien vuelven a hacer girar), con lo que se revela la comprensión intuitiva de ese estado espiritual, a veces llamado preñez, que ha de llevar a la unión mística y está asociado con vagos caprichos y anhelos (el hambriento que no sabe qué elegir, la mujer encinta llena de antojos extraños, el niño absorbido en el juego del escondite, el boceto que espera su color). Francia no carece enteramente de este elemento hispánico de la esperanza, pero le concede lugar muy limitado y sólo en lo ontológico, como de costumbre, y no en lo psicológico, y transforma en esa dirección los símiles españoles. Las pruebas pasivas que preparan la unión mística aparecen bajo las siguientes formas: los dolores que anuncian el parto, el paralítico del 
Evangelio, ansioso de las aguas removidas por el ángel, el lienzo que espera su pintor.

Francia atiende más que España al problema ontológico del alma que bajo los rayos de la gracia se ve a sí propia inferior e indigna. No se empeña en resolver un problema, sino en descubrir una ley in spiritualibus, intento que hizo famoso a Malebranche. Así la terrible sorpresa del aparente descenso del alma se ilustra mediante símiles de ley natural (la costra que se resquebraja y da salida al fétido olor del tremedal, la gruta seca invadida por el agua, la cría del cuervo que necesita recibir alimento de sus padres, pero teme su negro plumaje, el aguilucho a quien su madre lleva a una alta roca para que aprenda a mirar el sol, el buen médico que usa dolorosos emplastos, el niño a quien castigan para educarlo). Francia subraya además, con preciosismo ultraintelectual, uno de sus elementos místicos predilectos, el llamado pur amour, la adhesión radical a Dios, acompáñese o no de satisfacciones para el alma. Hay, pues, una serie de símiles referentes a la Sainte Indifférence del alma en estas pruebas (el arpista sordo que toca a pesar de su sordera, el niño obediente que toma una medicina desagradable, el valiente soldado que no necesita de música guerrera para ir a la batalla).

En general, por lo que atañe a las pruebas pasivas, los españoles, descubridores del Nuevo Mundo, descubren aquí un nuevo mundo interior, donde la gracia se recibe a costa del sufrimiento. El pueblo de los autos de fe y de la imaginación siniestra no escatima horrores para describir la purificadora noche oscura de esos sufrimientos. Pero el espíritu de la Reconquista, con su comprensión intuitiva del sufrimiento, pone esperanza en la desesperación. Los franceses hacen amplias y "retrospectivas" variaciones sobre el descubrimiento español de la noche oscura, racionalizándolo y sintetizándolo. Extienden los horrores descritos por los españoles hasta la naturaleza inanimada, e intentan hacer de la experiencia mística una ley teológica.

Los símiles para la unión mística inceptiva son, en los españoles, muy parecidos a los de la quietud inceptiva. El elemento de sorpresa radical se nos presenta realzado por el de vehemencia y elaborado psicológicamente (cometa, silbo, trueno, relámpago, chispas del pedernal, torrente, vasija rebosante). Los franceses, mesurados, no dan ejemplos de ese tipo. Ofrecen en cambio algunos, ingeniosamente trabajados, para el arrobamiento (el pigmeo trans, formado en gigante, la alondra que remonta el vuelo, los ruiseñores felices en su silencio). Un segundo aspecto de la unión inceptiva es el fugaz anticipo de la unión permanente. Los símiles españoles (olor del melón, virtud de la piedra preciosa, el amigo cuya presencia se adivina en la oscuridad) no son en este punto diferentes de los franceses (el esposo sentado en plácida y silenciosa compañía de su mujer, la Magdalena a los pies del Señor, el niño que quisiera penetrar en el seno materno), sólo que no reflejan exclusivamente relaciones humanas y no están libres de supersticiones.

Los símiles tradicionales españoles que explican cómo Dios traspasa el alma aparecen más cuidadosa e ingeniosamente rejuvenecidos en viejas y familiares imágenes (el hierro al rojo, el sol en la nube, el rayo de sol en suspenso o en la vidriera, el leño en llamas, la luz de dos velas, las estrellas bajo la luz del sol, la 
luz que entra dividida en una pieza y que se unifica luego). Francia, racionalista y académica, transforma estéticamente los antiguos símiles (el haz de paja en el fuego, el sol que traspasa la vidriera, las estrellas traspasadas por el sol) sin añadir nada nuevo.

Los españoles, que sólo parcialmente siguen la tradición nórdica de Ruys. broeck, tienen unos pocos símiles referentes a la sumersión del alma en Dios (el buzo, la esponja en el agua, la lluvia en el mar). Francia, que desde Gerson vive casi exclusivamente de la tradición flamenca, y restringe ahora cuidadosamente las posibles implicaciones de panteísmo, desarrolla los símiles de la sumersión en otros de absorción que subrayan la conciencia del elemento ab. sorbido (la gota de agua en el mar, el líquido en que se empapa la esponja, el bálsamo en el algodón, el derretirse un objeto en el fuego, el átomo perdido en un horno o en las manos de un gigante, el pececillo en el océano).

Los procesos que se manifiestan post matrimonium mysticum como la su. prema bienaventuranza imaginable sobre la tierra -en cuyas implicaciones teológicas no podemos deternos aquí- se explican por primera vez con símiles españoles en los escritos de San Juan de la Cruz. Estos símiles son prácticamente los de la penetración, sólo que con mayor grado de energía y vehemencia (la luz del sol que se clarifica más en el aire limpio de vapores, las chispas en el horno cuando lo avivan, las centellas en la llama). En este punto los franceses intentan afanosamente avanzar en distintas direcciones, aunque sin alcanzar la claridad de San Juan de la Cruz (la esponja llena de agua y agitada en el mar, inspirar y espirar, sístole y diástole), o describen con una pointe el frágil muro que separa cielo y tierra (el cuerpo ya casi consumido del leproso).

En general los españoles expresan directamente su experiencia de la unión mística con todo lo que tiene de sorprendente y arrebatadora y utilizan para ello, con suma originalidad, materiales tradicionales. Los franceses prefieren teorizar sobre la unión mística; en sus analogías insisten particularmente en relaciones humanas, y utilizan su rica tradición nórdica excediéndose tan sólo en los detalles para evitar el "quietismo". Académicos y racionalistas, intentan descubrir nuevas tierras, pero no llegan a más profundidad que los españoles. Más bien reemplazan la profundidad por la vivacidad y las pointes, mientras que los españoles, en este terreno sagrado, se abstienen por completo de toda agudeza. 